\title{
Evaluation Of The Federal-State Cooperative Observation Well Network In Upstate New York, 1995-97
}

By Richard J. Reynolds

U.S. GEOLOGICAL SURVEY

Open-File Report 99-468

Prepared in cooperation with the

NEW YORK STATE DEPARTMENT OF ENVIRONMENTAL CONSERVATION 


\title{
U.S. DEPARTMENT OF THE INTERIOR BRUCE BABBIT, Secretary
}

\author{
U.S. GEOLOGICAL SURVEY \\ Charles G. Groat, Director
}

For additional information write to:

U.S. Geological Survey

425 Jordan Road

Troy, NY 12180-8349
Copies of this report can be purchased from:

U.S. Geological Survey

Branch of Information Services

Box 25286

Denver, CO 80225 


\section{CONTENTS}

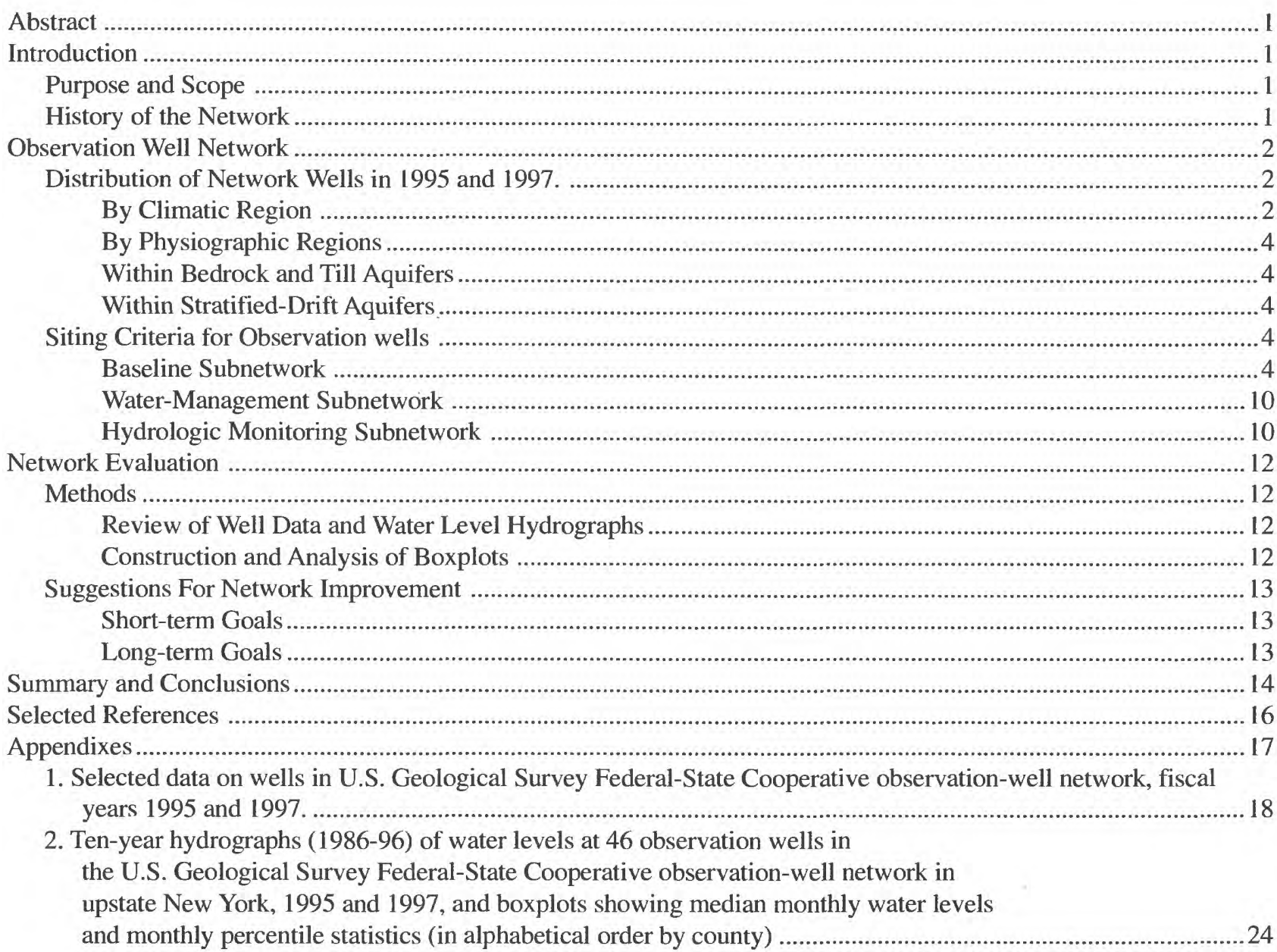

\section{FIGURES}

\section{1-5. Maps showing:}

1. Location and distribution of observation wells in the Federal-State cooperative network in New York in 1995 and 1997

2. Distribution of observation wells within climatic regions of New York in 1995 and 1997

3. Distribution of observation wells within physiographic provinces of New York in 1995 and 1997

4. Distribution of observation wells among generalized bedrock units of New York in 1995 and 1997

5. Distribution of observation wells among stratified-drift aquifers of New York in 1995 and 1997

6. Hydrograph showing water levels in well A-637 in relation to total monthly pumpage

from Guilderland municipal well field, 1987-94

7. Map showing Drought Regions in New York State and proposed areas for expansion of observation well network ..15

\section{TABLES}

1. Summary of objectives and products of three types of observation well networks .9 
CONVERSION FACTORS, ABBREVIATIONS, AND VERTICAL DATUM

\begin{tabular}{rcl}
\hline Multiply & by & To Obtain \\
\hline inch (in.) & Length & \\
foot (ft) & 2.54 & centimeter \\
mile (m) & 0.3048 & meter \\
& 1.609 & kilometer \\
& 0.1894 & meter per kilometer \\
foot per mile (ft/mi) & Area & \\
& 2.59 & square kilomter \\
\hline
\end{tabular}

Sea level: In this report, "sea level" refers to the National Geodetic Vertical Datum of 1929 (NGVD of 1929)-a geodetic datum derived from a general adjustment of the first-order level nets of the United States and Canada, formerly called Sea level Datum of 1929. 


\title{
Evaluation Of The Federal-State Cooperative Observation Well Network In Upstate New York, 1995-97
}

\author{
By Richard J. Reynolds
}

Abstract

The U.S. Geological Survey's Federal-State cooperative observation well network in upstate New York was evaluated in terms of areal coverage, objectives, and short- and long-term expansion plans. This report presents a history of the observation well network in upstate New York and depicts, on maps, the distribution of observation wells with respect to climatic regions, physiographic regions, and aquifer type (bedrock, till, and stratified drift) within New York State. It also describes siting criteria for observation wells, outlines the objectives of three types of observation well subnetworks, and offers suggestions for short- and long-term improvements of the current network. Two appendixes contain (1) a table of selected well data, and (2) hydrographs and boxplots that show median monthly water levels and monthly percentile statistics for water levels in the 46 observation wells.

\section{INTRODUCTION}

The U.S. Geological Survey (USGS) has maintained an observation well network in upstate New York (excluding Long Island) since 1933, funded largely through a cooperative program with the New York State Department of Environmental Conservation (NYSDEC). Under this program, the costs of maintaining the network (known as the USGS Federal-State cooperative observation well network) and processing and publishing the resulting data are shared between the USGS and the NYSDEC. In 1996, the observation well network in upstate New York was drastically reduced in size, from 46 wells to 8 wells, in response to a reduction in State funding. Funding was partly restored the following year and, since 1997, the network has consisted of 15 wells. In 1998, the USGS, in cooperation with the NYSDEC, conducted a study to (1) evaluate the 1997 observation well network in terms of hydrologic objectives, adequacy of coverage, and degree to which the network meets its objectives, and (2) to make specific suggestions for improving the network.

\section{Purpose and Scope}

This report describes the observation well network in upstate New York for 1995 and 1997, outlines the development, history of the network, describes the hydrologic objectives of several categories of observation well sub-networks and the criteria for well selection, and tabulates selected data for the wells in the 1995 and 1997 networks. It also presents both specific and general suggestions for the future expansion and improvement of the network. A table of selected well data, along with ten-year hydrographs and boxplots showing median monthly water levels and monthly percentile statistics for water levels in the observation wells in the 1995 and 1997 networks are presented as appendixes.

\section{History of the Network}

The U.S. Geological Survey began a formal, nationwide observation-well program in 1934 that was subsequently expanded in response to the drought of the mid-1930's. The USGS Federal-State cooperative observation-well program in New York began in 1933 with the installation of three wells as part of a long-term study of reforestation in Cortland County in central New York. Water-level data from this study were subsequently published (Harrington, 1935); however, a statewide network of observation wells was not officially established until the USGS began a series of county ground-water studies in cooperation with the NYSDEC (then the New York State Conservation Department) and the New York State Water Power Control Commission during the 1940's and 1950's.

Temporary observation wells were established as part of these county ground-water studies to obtain data on local hydrologic conditions in each study area. As each study ended, selected wells were retained and incorporated into the statewide network. Most of these wells were privately owned, and because they had either been previously abandoned or were otherwise unused, the owners had allowed 
works were sparse in the four northern regions and were absent in the Champlain Valley and eastern Great Lakes regions.

\section{By Physiographic Regions}

The distribution of observation wells with respect to physiographic region was examined because local topography can affect ground-water levels and because regional physiography, in part, controls the directions of regional ground-water flow. New York State has been divided into nine physiographic provinces by Fenneman (1938) and Thompson (1966). The distribution of network wells in 1995 and 1997 with respect to physiographic province is shown in figure 3. Most of the observation wells are in the Appalachian Upland and Hudson-Mohawk Lowland provinces; coverage within the Adirondack Mountains is extremely sparse.

\section{Within Bedrock and Till Aquifers}

The distribution of observation wells completed in bedrock and till aquifers was examined because most of the rural population of upstate New York relies on self-supplied water from drilled or dug domestic wells. The observation well network in 1995 contained seven wells that were completed in bedrock-aquifer systems, most of which are in southeastern New York (fig. 4), and eight wells completed in till deposits, most of which are in upland settings. In 1997, however, the network contained one bedrock well and only one well completed in till. Bedrock aquifers, especially the large regional sandstone aquifers that underlie the Tug Hill Plateau and the Ontario and St. Lawrence Low lands (fig. 4), are poorly represented in the upstate observation well network.

\section{Within Stratified-Drift Aquifers}

Stratified-drift aquifers are the main focus of the upstate observation well program because most of the publicly supplied ground water in upstate New York is pumped from these aquifers. Of the 46 wells in the 1995 network, 26 were completed in stratifieddrift aquifers, 17 of which are in valley-floor settings, and 9 of which are in upland or hillslope settings. The distribution of network observation wells completed in stratified-drift aquifers in 1995 and 1997 is shown in figure 5. Eight of the 17 valleyfloor observation wells in the 1995 network were classified as "water-management" wells and were screened in 7 of the 18 primary aquifers as defined by the New York State Department of Health (Waller and Finch, 1982; Cosner, 1984). The remaining 18 network wells completed in stratified-drift aquifers in 1995 were classified as "baseline" wells. Two of the 9 upland wells in the 1995 network were classified as "water-management" wells because they were completed in aquifers that are intermittently used for public supply.

Of the 16 wells in the 1997 network, 14 were completed in stratified drift, one in bedrock, and one in till. Twelve of the 16 wells were considered "baseline" wells, and 4 were considered "watermanagement" wells. Seven of the 16 wells were in valley-floor settings, 3 were in upland-plain settings, 2 were in upland settings, 2 were in plain settings, one was in an upland valley setting, and one was in a hilltop setting.

\section{Siting Criteria for Observation wells}

The upstate observation-well network consists of two subnetworks- - "water management" and "baseline"-each of which has separate objectives and, thus, somewhat different siting criteria. A third type of subnetwork, a "hydrologic monitoring" network, is used to monitor the effects of local hydrologic stresses in individual aquifers. These three types of observation-well subnetworks are described in Heath (1976); the objectives and products of each are summarized in table 1 .

\section{Baseline Subnetwork}

The objectives of the baseline subnetwork, as indicated in table 1, are to: (1) indicate the effects of climatic changes (seasonal variations in recharge) on ground-water storage, and (2) define the effect of topography and(or) geologic conditions on the response of water levels to climatic changes. Ideally, this subnetwork would consist of observation wells screened in major unconfined (water-table) sand and gravel aquifers in areas not significantly affected by ground-water withdrawals or artificial recharge. Water-level data from this subnetwork would indicate only the response of the ground-water system to seasonal and long-term variations in recharge and, thus, would provide baseline data needed to interpret data from the water-management subnetwork and any detailed hydrologic subnetworks. 


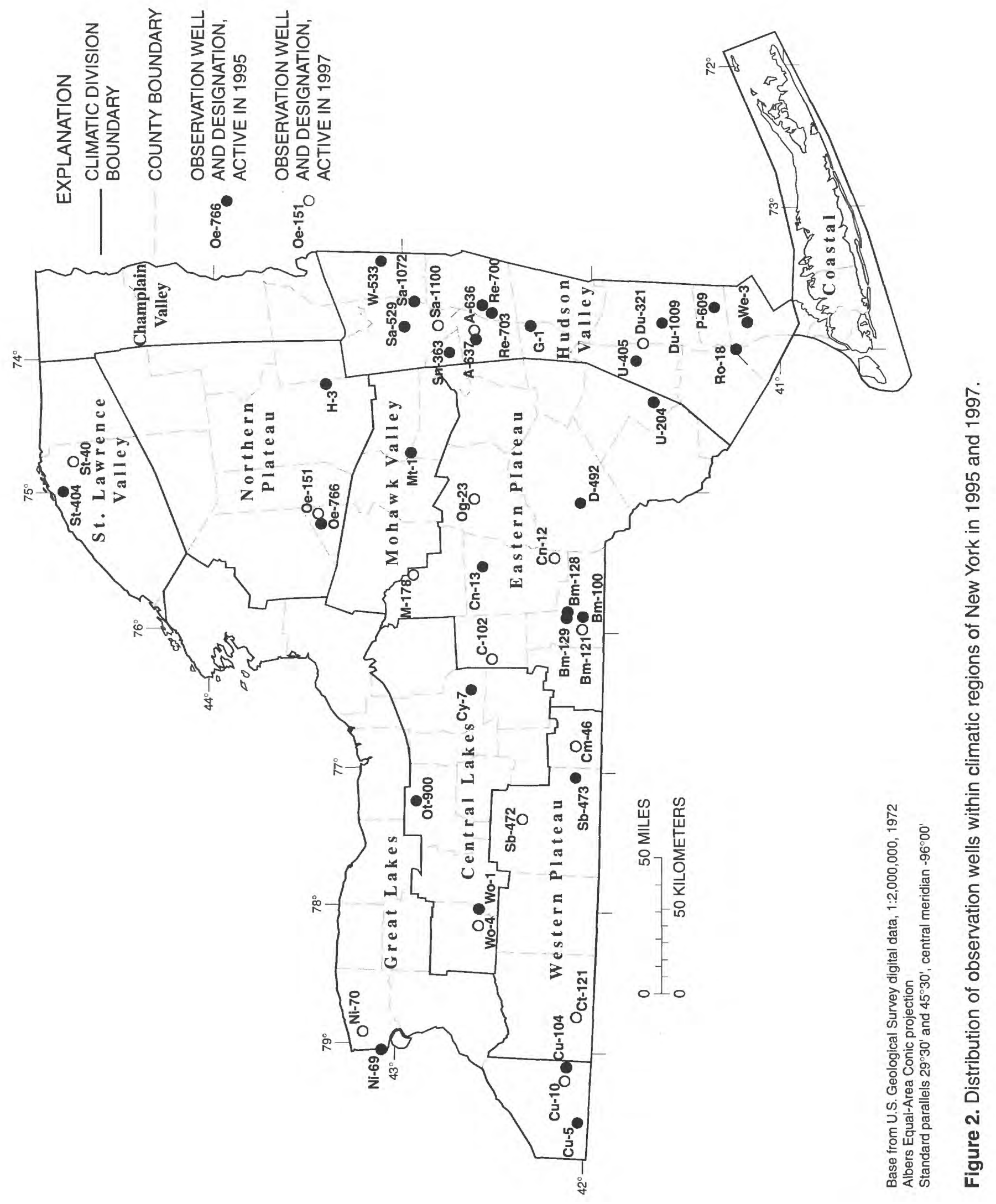




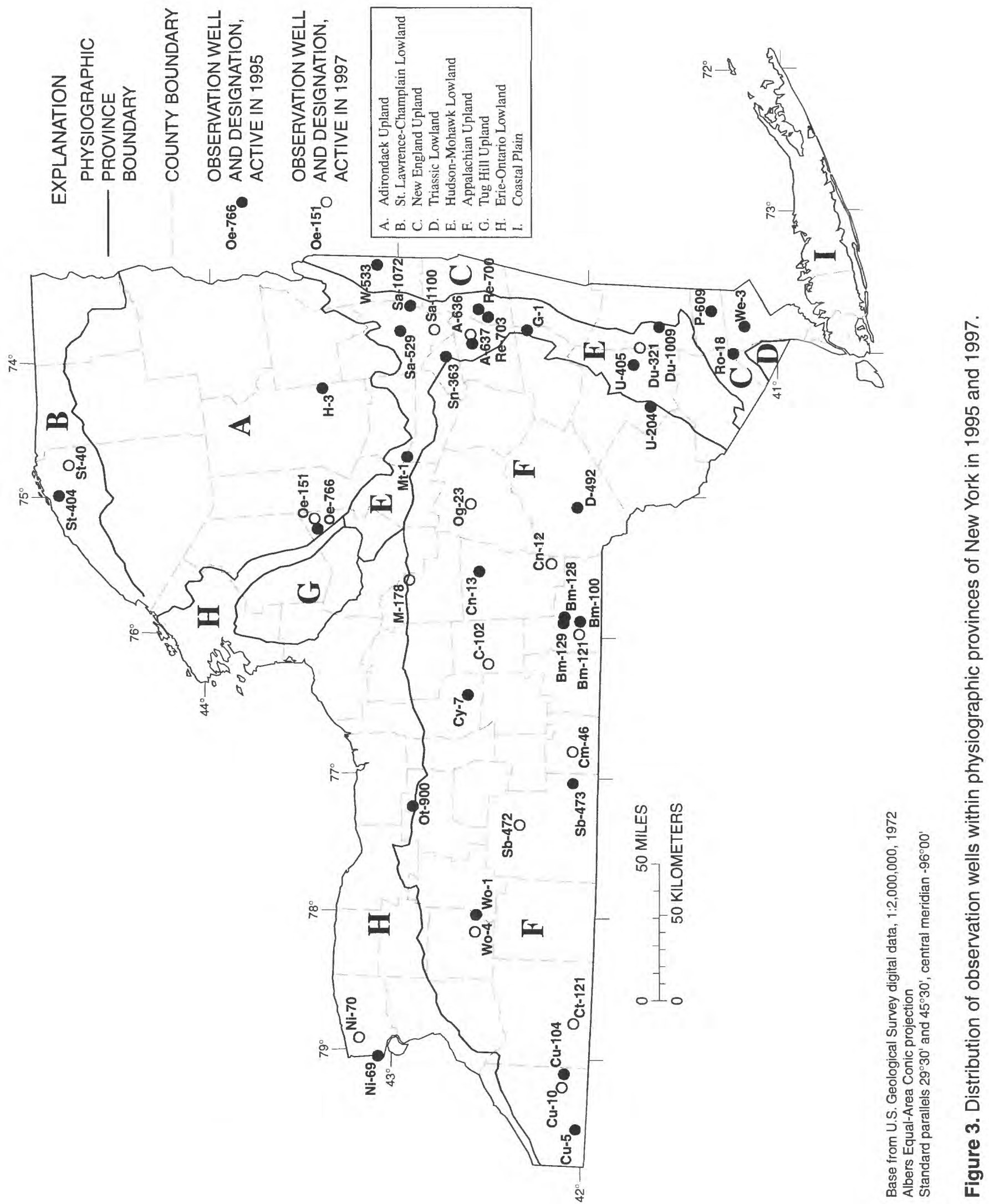



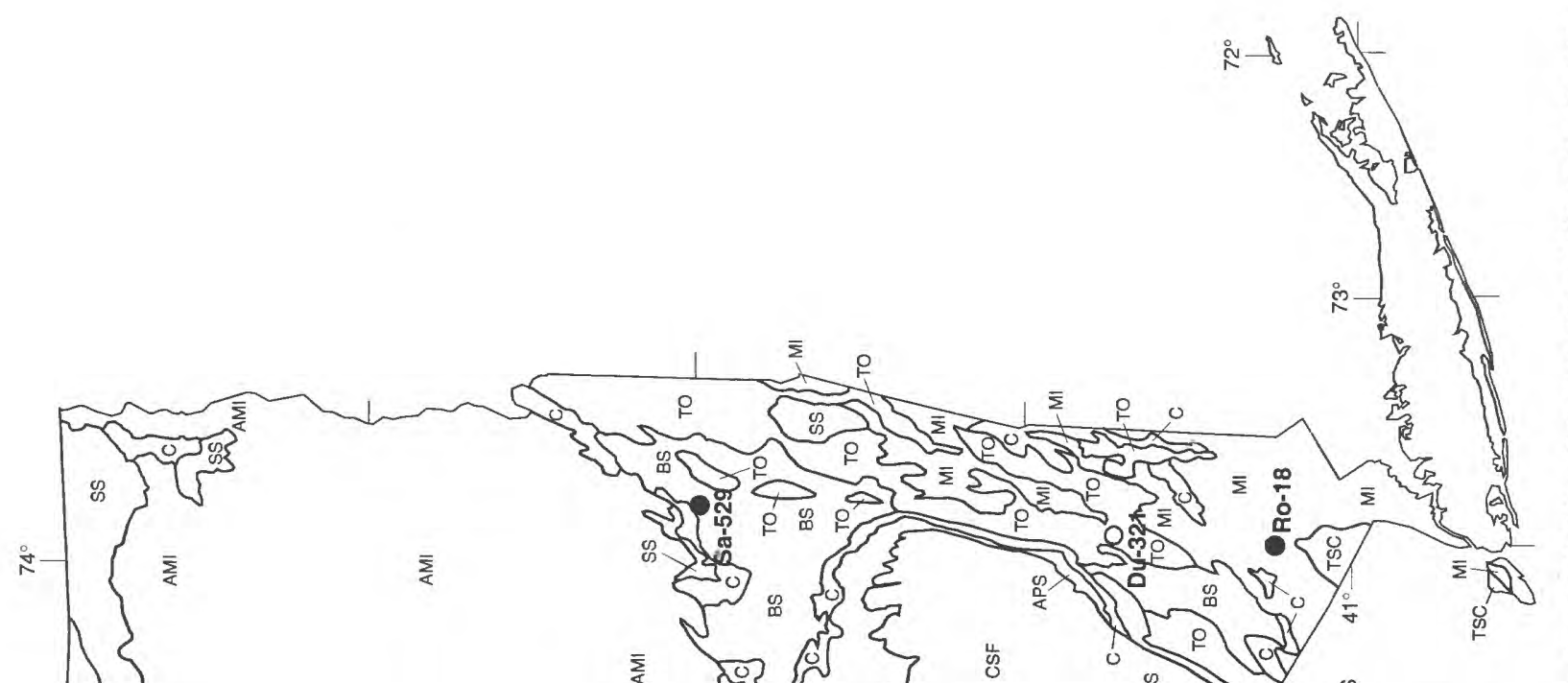

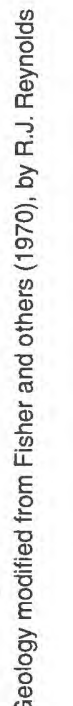

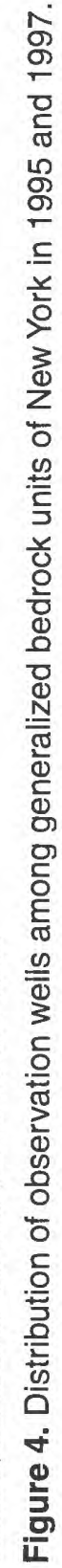




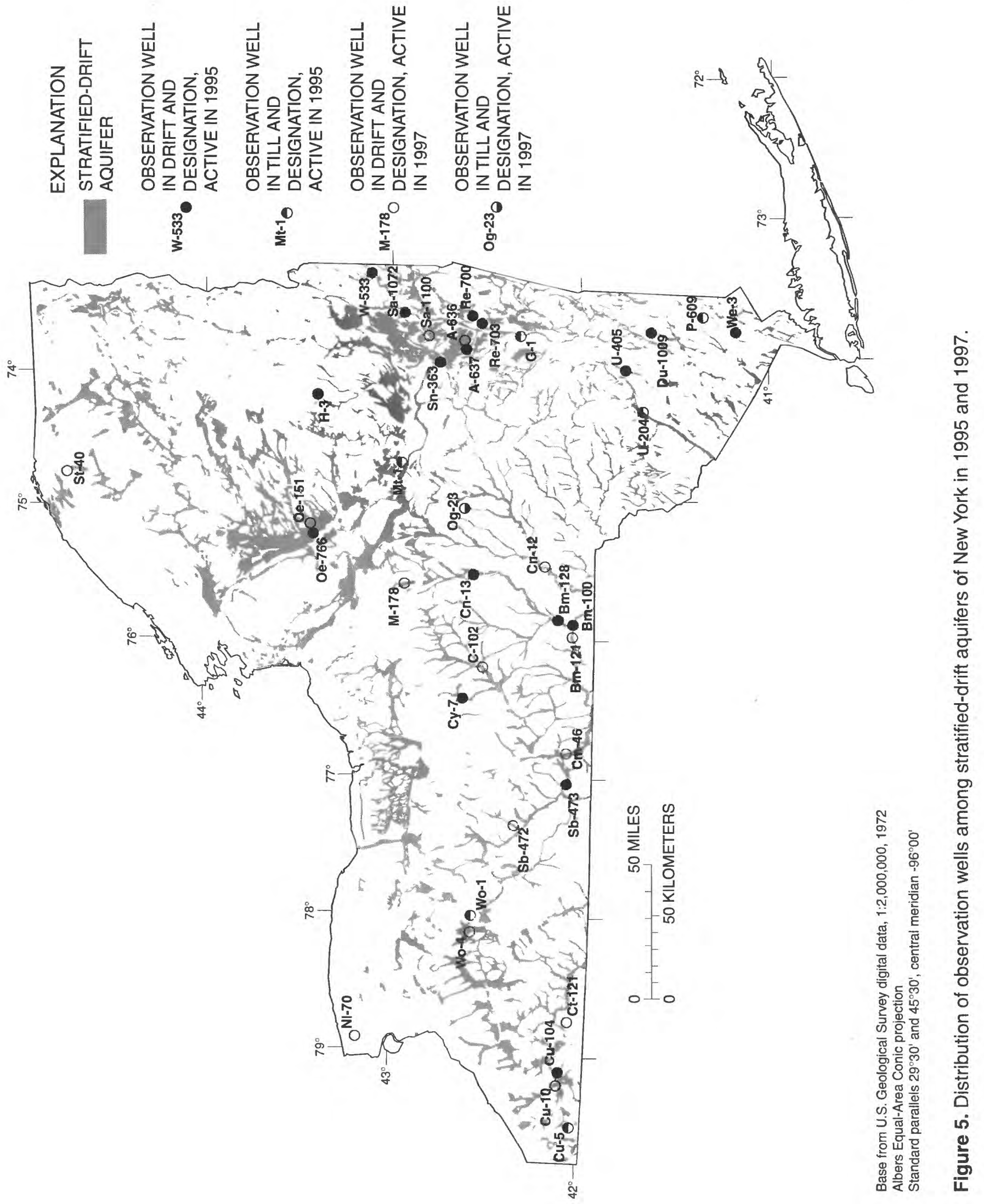


The typical baseline-well subnetwork can be divided into groups $\mathrm{A}$ and $\mathrm{B}$ (table 1), as follows:

Group A-This group consists solely of wells that indicate only the effect of areal variations in precipitation on ground-water storage. Ideally, all wells in this group would be of nearly identical construction and would be located in areas with nearly identical geologic and topographic conditions. For valley-fill aquifers, this means that all wells would be located on the valley floor, but away from rivers or streams that could induce water-level fluctuations in the well. Further requirements for these wells, as outlined by Heath (1976), are that:

1. The wells are screened in the unconfined (watertable) aquifer, which typically responds more directly to recharge and evapotranspiration than do confined aquifers.

2. The depth to the water table below land surface is roughly the same at all wells so that traveltime for recharge through the unsaturated zone can be ignored in hydrograph comparisons between wells.

3. All wells are in a similar topographic setting to eliminate the effects of local topography on water levels.

4. All wells have a similar casing diameter, screen length, and general construction.
In addition, these wells should be installed far enough away from surface-water bodies (especially rivers and streams) that can induce, or moderate, water-level fluctuations in the aquifer. In valley-fill aquifers, this could mean installing the well on the opposite side of the valley from a river that flanks a valley wall. Ideally, observation wells that are used to monitor changes in storage in valley-fill (or sandplain) aquifers would be installed close to a groundwater divide to insure that:

1. The well will be located in an area of ground-water recharge, not discharge, and

2. The well will, in all probability, record the greatest changes in storage at this location than at any other in the aquifer.

Group B-This group consists of wells needed in the evaluation of the effect of topography and geologic conditions on the response of aquifers to fluctuations in recharge. Wells in this group ideally would be placed near some or all of the wells in group A, but in different topographic settings and(or) completed in different aquifers. For example, an existing group A observation well completed in a surficial outwash aquifer might be paired with a new group B well completed in either an underlying confined ice-contact sand and gravel aquifer or in the underlying bedrock; alternatively, it might be paired with group B wells finished in till or bedrock on the adjacent hillsides and hilltops.

Table 1. Objectives and products of three types of observation-well subnetworks [From Heath, 1976, table 2].

\begin{tabular}{|c|c|c|}
\hline Type & Objectives & Products \\
\hline $\begin{array}{l}\text { Hydrologic } \\
\text { monitoring }\end{array}$ & $\begin{array}{l}\text { Define status of ground-water storage } \\
\text { Delineate areal extent of aquifers }\end{array}$ & $\begin{array}{l}\text { Regional water-table and(or) potentiometric-surface maps } \\
\text { Maps showing net change on water levels or storage over } \\
\text { a selected period }\end{array}$ \\
\hline \multirow[t]{3}{*}{$\begin{array}{l}\text { Water } \\
\text { management }\end{array}$} & $\begin{array}{l}\text { Measure effect of stresses on recharge and } \\
\text { discharge conditions }\end{array}$ & Local water-level maps \\
\hline & Estimate hydraulic characteristics of aquifers & Hydrographs showing change in water levels through time \\
\hline & Estimate degree of confinement & Graphs of water levels in relation to pumping rates \\
\hline $\begin{array}{l}\text { Baseline } \\
\text { (storage) }\end{array}$ & $\begin{array}{l}\text { A. Define effects of climate on ground-water storage } \\
\text { B. Define effect of topography and geologic } \\
\text { conditions on water-level response to climatic } \\
\text { fluctuations }\end{array}$ & $\begin{array}{l}\text { Hydrographs showing storage changes in different aquifers } \\
\text { and topographic settings within each climatic zone }\end{array}$ \\
\hline
\end{tabular}




\section{Water-Management Subnetwork}

The primary objective of the water-management subnetwork is to quantify the effect of ground-water withdrawals (or injection) on aquifer storage and natural aquifer discharge. This type of network provides (1) information on the response of groundwater systems to pumping-induced stresses, and (2) water-level data needed for management decisions.

The number of wells needed in a water-management network will differ from place to place, depending on the type of aquifer and the number and magnitude of pumping centers. Heath (1976) notes that, ". . . as a minimum, at least one observation well should be located near every major pumping center" and further stipulates that "near" in this context means that the observation well should be placed close enough to the pumping center to record the composite drawdown of the wellfield, but not so close to any specific pumping well that the pumping well's daily cycle of operation obscures the effects of more distant wells. Ideally, the observation wells near major pumping centers would be screened in the production zone and placed at various distances from the pumping center and, if feasible, would include wells screened in the overlying zone as well as the underlying zones to indicate the three-dimensional response of the ground-water system to pumping. Properly placed observation wells in a water-management network are reliable indicators of overdevelopment, or "mining", of ground water. A sample hydrograph from a properly placed water-management well (well A637, in Guilderland, N.Y.; for calendar years 1987-93) and a bar chart of the corresponding total monthly pumpage from the Guilderland municipal wellfield, approximately 0.5 mi northwest of A637, is shown in figure 6. The observation well (A637) and the three pumping wells at the wellfield are screened in a confined, icecontact sand-and-gravel deposit about $200 \mathrm{ft}$ below land surface. The hydrograph clearly shows that, as total monthly withdrawals from the wellfield fluctuated between 10 and 15 million gallons for the winter months to more than 25 million gallons for the summer months from 1987 through 1990, the potentiometric surface declined concurrently, with cyclical water-level fluctuations superimposed on the declining water level trend. When winter pumpage was sharply curtailed, starting in December 1990, the water level quickly responded, and rose during the fall and winter of each successive year until 1994, when it reached pre-pumping levels.

\section{Hydrologic Monitoring Subnetwork}

A hydrologic monitoring subnetwork consists of observation wells installed at multiple locations to monitor the local water-level response to fluctuations in recharge to, and pumping from, a single local or regional aquifer. Water levels in hydrologic monitoring subnetworks for specific aquifers generally are measured on the same day, several times a year, in order to develop a synoptic map of the water table or potentiometric surface. Such networks are valuable because successive sets of water-level measurements permit the construction of "net change" maps that indicate (1) temporal trends in water levels, and (2) areas where ground-water storage has been depleted and where recharge is taking place.

The installation of such networks to permit construction of water-table or potentiometric-surface maps and net-change maps can be thought of as an ultimate goal for the ground-water management of upstate aquifers. Such networks are in place for only a few aquifers in upstate New York, however, because their installation and maintenance are costly. Most of the existing hydrologic monitoring networks in New York are the result of current or past USGS ground-water investigations. These networks generally are not maintained by the USGS after a study has been completed, but, some local cooperating agencies have continued to make regular water-level measurements and to maintain the wells in certain networks. Some recent or current hydrologic monitoring networks in upstate New York include those in the Otter-Creek/Dry-Creek aquifer at Cortland, the Irondo-Genesee aquifer in Monroe County, a network at Olean, and a network in Clifton Park. Of these, only the Irondo-Genesee and the Clifton Park networks are currently (1999) being monitored.

The establishment of hydrologic monitoring networks requires considerable time and expense because the elevation of the measuring point of each well must determined to $1 / 100 \mathrm{ft}$ through leveling procedures. This is necessary so that (1) the elevation of the water table or potentiometric surface above sea level can be measured precisely, and (2) successive water-level measurements can be accurately compared. The most comprehensive hydrologic monitoring network maintained by the USGS in New York is on Long Island, where 617 wells are measured annually to produce potentiometric maps of the three main aquifers (upper glacial, Magothy and Lloyd) (Busciolano and others, 1998). 


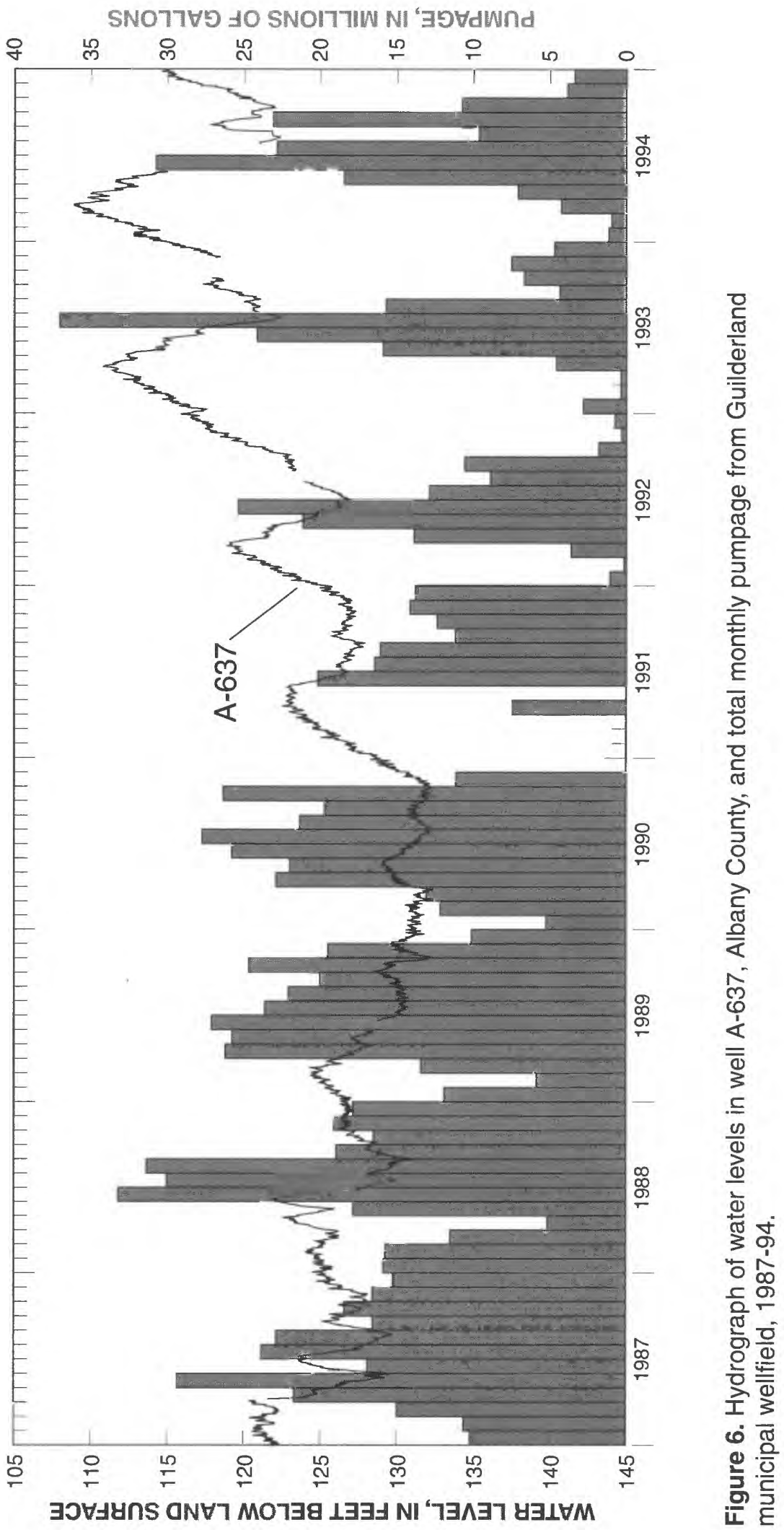




\section{NETWORK EVALUATION}

The statewide observation well network has been in continuous operation (in the present form) since 1965, and its operation within New York is evaluated periodically. Individual wells that constitute the network in any given year are evaluated on an annual basis as part of the management of the network.

\section{Methods}

The annual evaluation includes an inspection of the annual hydrograph of each well to determine whether the water level was responding to recharge and(or) nearby pumping (if a management well), or whether the water level record was being affected by changes in stage of a nearby stream. Results of these annual evaluations are summarized and stored in each individual well's file. The annual evaluations of individual wells were supplemented by network evaluations conducted in 1968 by W.A. Hobba, Jr. (U.S. Geological Survey, written commun.) and in 1985 by R. M. Waller (U.S. Geological Survey, written commun.). These evaluations were never published, but their major recommendations for network improvement are incorporated into the present study.

\section{Review of Well Data and Water Level Hydrographs}

In this study, each well's file was examined and notations made regarding previously described deficiencies in well placement, performance, and(or) construction. Previous recommendations for replacement of wells are incorporated into this report because the original reasons for replacement of most wells have not changed. The finished well depth was compared with the lowest water level on record for each well to identify those wells that do not penetrate far enough into the saturated zone and, thus, should be replaced or deepened. A hydrograph of the last 10 years was plotted for each of the 46 observation wells in the 1995 network and examined to verify that each well was responding to seasonal and annual variations in recharge; in addition, boxplots of median monthly water levels at each well were generated. The 10-year hydrographs and boxplots for each well are shown in appendix 2 .

\section{Construction and Analysis of Boxplots}

Boxplots are a method used to graphically summarize the characteristics of one or more data sets. They are commonly used as alternatives to histograms and are particularly useful for comparison of multiple data sets. The boxplots in appendix 2 display:

1. The median value of the data (the median is shown by the center line of the box)

2. The variation or "spread" of the data (indicated by the 75 th and 25 th percentile of the values), referred to as the interquartile range and indicated by the box length.

3. The skewness of the data set, as indicated by the size of the box halves and length of whiskers. The 90 th and 10th percentiles are represented by the whisker ends.

4. The presence of unusual or extreme values, shown as an asterisk.

The boxplots of median monthly water levels can be used to assess the variability of water levels from month to month at the same well, and, when taken as a 12-month data set, can be used to qualitatively compare the annual variability of water levels at two or more wells. The plots give median monthly water levels (for the period of record); the 90th, 75th, 25 th, and 10th percentiles; and the presence of extreme water levels (outliers) shown as an asterisk. The boxplots also show whether the data are approximately symmetrical about each monthly mean or are skewed, and can help to indicate whether water levels at a particular well are highly responsive to recharge events (indicated by extreme variability in spring) or are affected by nearby pumping (extreme variability in summer and autumn).

A boxplot of a water-level data from a "baseline" well that responds only to natural fluctuations in recharge would be expected to show approximately the same range of water-level fluctuation in each month, as shown, for example, by well A-636 (appendix 2, fig. A1). Similarly, a boxplot of a well that is affected by nearby pumping such as wells Sa1100 (fig. A5) and Bm-128 (fig. B1), or by stage fluctuations in a nearby stream, will indicate large fluctuations in water levels, particularly during the late summer. 


\section{Suggestions For Network Improvement}

Only 16 of the 46 wells in the upstate FederalState Cooperative Network were funded and continued to operate in 1997. Suggestions to improve this network to meet its objectives can be grouped into two categories-short-term goals and long-term goals.

\section{Short-term Goals}

The main short-term goal is the reactivation of (1) discontinued wells in the "baseline" and "watermanagement" subnetworks, and (2) wells that reflect long-term changes in storage in the State's stratifieddrift aquifers. This reactivation will help meet the objectives of the NYSDEC and the State Department of Health, as expressed in their "Framework for Ground-Water Management" (1982), which is:

"... to assure that ground-water withdrawals do not endanger the value of the aquifer and to monitor ground water to determine baselines and trends. ..".

Specific wells that warrant reactivation include:

1. A-637, a "water-management" well in Guilderland (Albany County), that reflects municipal pumping from a segment of the confined Colonie Channel aquifer. Period of record 1976-95.

2. Re-703, a "water-management" well in East Greenbush (Rensselaer County) and screened in ice-contact deposits of the Schodack Terrace aquifer. Period of record 1982-95.

3. W-533, a "baseline" well in Washington County that reflects natural fluctuations in storage in a valley-fill aquifer. Period of record 1965-95.

4. Bm-100, a "baseline" well at the eastern end of the Johnson City-Binghamton primary aquifer (Broome County) that reflects natural fluctuations in storage. Period of record 1946-95.

5. Bm-128, a "baseline" well in Kattelville (Broome County), that monitors natural fluctuations in storage in a separated segment of valley-fill aquifer. Period of record 1980-95.

6. Cn-13, a "baseline" well in a separated valley-fill aquifer (without a major stream) near Sherburne, Chenango County. Designed as a network well, it reflects natural fluctuations in storage in an area unaffected by municipal pumping. Period of record 1980-95.

\section{Long-term Goals}

One of the main uses of the upstate network is to ascertain the status of ground-water storage in primary aquifers during drought conditions. Two priority long-term goals, therefore, are to (1) replace observation wells currently in either the "watermanagement" or "baseline" category that provide marginal data because of either improper well placement, lack of well screen, insufficient depth, or infilling with sediment with 6-inch-diameter drilled wells equipped with appropriate screens, and (2) install similar new "water-management" and "baseline" wells in primary aquifers throughout the State. The first aquifers in New York State, that would indicate a decline in ground-water storage in response to drought conditions are those that do not discharge directly to a major stream or river system-notably sand-plain aquifers, bedrock or till aquifers, and, to some extent, headwater and separated-valley aquifers. These aquifers, therefore, warrant representative "baseline" wells within each of the climatic zones described previously.

The "baseline" subnetwork would require at least one well finished in the sandstone and limestone aquifers of the St. Lawrence, Lake Champlain, Eastern Lake Ontario, and Lake Erie drainage systems (fig. 1); these wells also would fill the data deficiencies for bedrock aquifers in the corresponding climatic divisions and physiographic regions. Additionally, one or more baseline observation wells are needed in the shales of the Appalachian Plateau and in the igneous-metamorphic system of the Adirondacks (fig. 4). Till aquifers in the uplands were comparatively well represented in 1995 but not in 1997; selected wells finished in till warrant reactivation as the network is rebuilt.

Discussions with NYSDEC staff concerning areas of upstate New York into which the network should be expanded resulted in the identification of six areas in which ground-water-level data from stratified-drift aquifers are needed. These areas are:

1. South Fallsburg, in Sullivan County or Port Jervis, in Orange County

2. the Mohawk-Little Falls-Fonda area, in Herkimer and Montgomery Counties 


\section{3. the Elizabethtown area, in Essex County}

\section{4. the Oswego area, in Oswego County}

5. the Seneca Falls - Auburn area, in Seneca and Cayuga Counties

\section{6. the Batavia area, in Genesee County}

The addition of baseline observation wells in these six areas would provide the necessary groundwater level data from stratified-drift aquifers needed during critical drought periods in NYSDEC Drought Management Regions 2, 4, 5, 6, and 7. The locations of these expansion areas and the NYSDEC Drought Management Regions are shown in figure 7.

In addition, many "water-management" wells screened in primary aquifers warrant evaluation for replacement in accordance with the site-selection criteria set forth by Heath (1976). For example, Schenectady County well Sn-363, a well that is not currently monitored, is screened within the cone of depression of the Schenectady well field and might be supplemented or replaced by a current NYSDEC observation well, about $2,000 \mathrm{ft}$ to the southeast, and whose location might be better suited to record the collective drawdown of the wellfield. Other primary aquifers may require additional observation wells that meet the siting criteria for "water-management" wells. In addition, some of the current "baseline" wells are now affected by nearby pumping and could, therefore, be reassigned to the "water-management" network, and replacement "baseline" wells could be installed in more appropriate locations within each aquifer. The hydrographs and monthly water-level boxplots generated for the 1995 network of 46 wells (appendix 2) were inspected to identify which wells reflected the effects of pumping, and which wells responded properly as "baseline" wells.

Water level data from the Statewide network are generally evaluated by NYSDEC staff on a monthly basis, whereas, water-level data from USGS recorder-equipped network wells are downloaded, evaluated, and made available to NYSDEC and the public on a 7-week basis. During periods of drought, however, changes in ground-water levels need to be monitored more frequently by the NYSDEC, perhaps on a weekly basis. These ground-water level data are an important basis for NYSDEC decisions as to whether conditions warrant the declaration of a drought "watch", drought "warning", or drought "emergency".
Ground-water data could be made available to NYSDEC on an as-needed basis if recorder wells that are not equipped with electronic data loggers were so equipped, and if wells that are measured manually were automated with electronic data loggers. Regional NYSDEC staff in each of the State drought regions could then be instructed how to retrieve the most recent water-level reading that was logged, this would allow a team of NYSDEC regional observers to relay water-level data to NYSDEC headquarters during critical drought periods on a weekly or even daily basis.

\section{SUMMARY AND CONCLUSIONS}

Immediate efforts and continued long-term efforts are needed to reactivate key discontinued wells and to improve the overall quality and distribution of the Federal-State cooperative observationwell network in upstate New York, if the network is to enable Federal, state, and local water agencies to assess the effect of short- and long-term drought conditions, as well as ground-water pumping, on ground-water storage. A total of six selected observation wells in the "baseline" and "management" subnetworks warrant reactivation as soon as funding permits. Long-term objectives for improving the network include (1) replacing wells of inadequate construction with 6-inch-diameter drilled wells equipped with appropriate screens, (2) replacing "water-management" wells that are screened within cones of depression with wells farther from pumping centers, and (3) installing new "baseline" wells in six areas of the State to monitor ground-water levels in stratified-drift aquifer within several NYSDEC Drought Management Regions. In addition, at least one observation well is needed in both the "baseline" and "management" networks for each State-designated primary aquifer to allow continual assessment of natural and pumping-induced changes in groundwater storage.

New wells need to be carefully sited and constructed to ensure that the resulting water-level data accurately represent fluctuations in groundwater storage in the aquifer in which they are screened. Water level data from regional sandstone and limestone aquifers in the northern part of New York are lacking; therefore, future network-expansion plans ideally would include new "baseline" wells in aquifers in this part of the State. Timely reporting of data from the upgraded network could be enhanced by selectively training Regional NYSDEC 


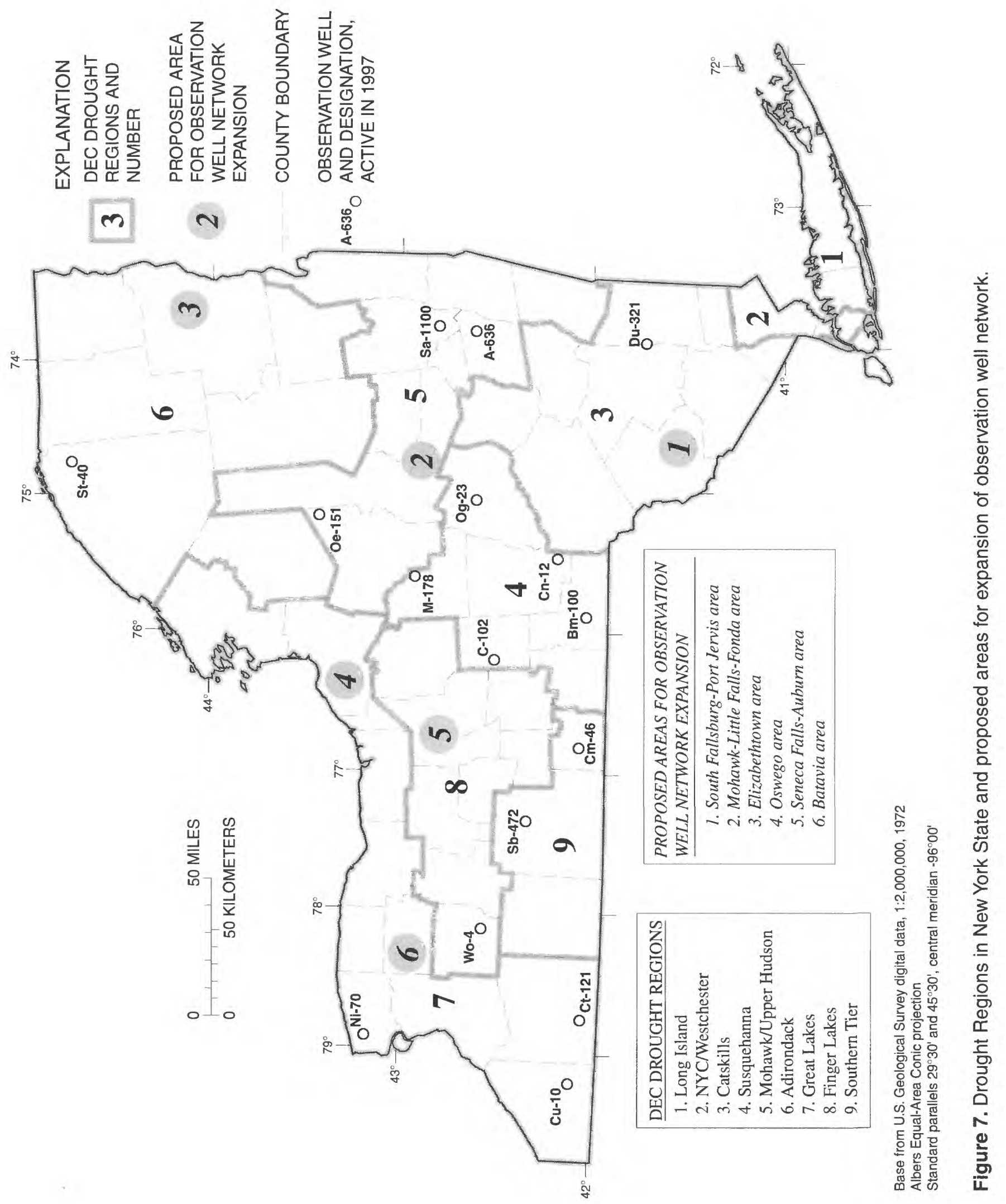


observers to access recorder-equipped observation wells in their respective Regions and thereby provide water-level data on a weekly or daily basis during critical drought periods.

\section{SELECTED REFERENCES}

Busciolano, Ronald, Monti, Jack Jr., and Chu, Anthony, 1998, Water-table and potentiometricsurface altitudes of the upper glacial, Magothy, and Lloyd aquifers on Long Island, New York, in March-April, 1997, with a summary of hydrogeologic conditions: U.S. Geological Survey Water Resources Investigations Report 98-4019, $17 \mathrm{p}$.

Cullings, E.S., 1936, Fluctuations in ground-water at Woodgate, New York: Transactions, American Geophysical Union, pt. 2, 17th Annual Meeting, National Research Council, Washington, D.C., July 1936, p. 357-360.

Cosner, O.J., 1984, Atlas of four selected aquifers in New York: U.S. Environmental Protection Agency report, contract no. 68-01-6389, Norman, Oklahoma, Engineering Enterprises 102 p.

Emery, F.E., 1889, Notes on fluctuations in the height of water in an unused well: New York Agricultural Experiment Station, 8th Annual Report, p. 374377.

Fenneman, N.M., 1938, Physiography of the eastern United States: New York, McGraw-Hill, 714 p.

Fisher, D.W., Isachsen, Y.W., and Rickard, L.V., 1970, Geologic map of New York: New York Museum and Science Service Map and Chart Series, No. 15, 5 sheets, 1:250,000 scale.

Harrington, A.W., 1935, Records of water levels in central New York, in Meinzer, O.E., and Wenzel, L.K., Water levels and artesian pressure in observation wells in United States, 1935: U.S. Geological Survey Water Supply Paper 777, p. 127-129.

Heath, R.C., 1976, Design of ground-water level observation well programs: Ground Water, v. 14, no. 2, p. 71-77.

Holland, W.T., and Jarvis, C.S., 1938, Inventory of unpublished hydrologic data: U.S. Geological Survey Water Supply Paper 837, 77 p.
New York State Department of Environmental Conservation and New York State Department of Health, 1982, New York State's framework for ground-water management-a program development strategy: mimeograph report, $17 \mathrm{p}$.

New York State Department of Health, 1981, Report on ground water dependence in New York State: New York State Department of Health, Bureau of Public Water Supply Report, 49 p.

Pack, A.B., 1972, The climate of New York, in Climates of the States, 1, Eastern States (plus Puerto Rico and the U.S. Virgin Islands): Syosset, N.Y., Water Information Center, p. 357-8.

Randall, A.D., 1996, Mean annual runoff, precipitation, and evapotranspiration in glaciated northeastern United States, 1951-80: U.S. Geological Survey Open-File Report 96-395, 2 sheets, scale $1: 1,000,000$.

Thompson, J.H., (ed.), 1966, Geography of New York State: Syracuse, N.Y., Syracuse University Press, 543 p.

Waller, R.M., and Finch, A.J., 1982, Atlas of 11 selected aquifers in upstate New York: U.S. Geological Survey Open-File Report 82-553, $255 \mathrm{p}$. 


\section{APPENDIXES}




\section{Appendix 1. Selected data on wells in U.S. Geological Survey Federal-State Cooperative observation-well network, fiscal years 1995 and 1997.}

\section{EXPLANATION OF COLUMN HEADINGS}

County well no.:

$\begin{array}{llll}\text { A } & \text { Albany County } & \text { Oe } & \text { Oneida County } \\ \mathrm{Bm} & \text { Broome County } & \mathrm{Og} & \text { Otsego County } \\ \mathrm{Ct} & \text { Cattaraugus County } & \mathrm{Ot} & \text { Ontario County } \\ \mathrm{Cy} & \text { Cayuga County } & \text { P } & \text { Putnam County } \\ \mathrm{Cu} & \text { Chautauqua County } & \mathrm{Re} & \text { Rensselaer County } \\ \mathrm{Cm} & \text { Chemung County } & \mathrm{Ro} & \text { Rockland County } \\ \mathrm{Cn} & \text { Chenango County } & \mathrm{St} & \text { St. Lawrence County } \\ \mathrm{C} & \text { Cortland County } & \mathrm{Sa} & \text { Saratoga County } \\ \mathrm{D} & \text { Delaware County } & \mathrm{Sb} & \text { Steuben County } \\ \text { Du } & \text { Dutchess County } & \mathrm{Sn} & \text { Schenectady County } \\ \mathrm{G} & \text { Greene County } & \mathrm{U} & \text { Ulster County } \\ \mathrm{H} & \text { Hamilton County } & \text { W } & \text { Washington County } \\ \mathrm{M} & \text { Madison County } & \text { We } & \text { Westchester County } \\ \mathrm{Mt} & \text { Montgomery County } & \text { Wo } & \text { Wyoming County } \\ \mathrm{Ni} & \text { Niagara County } & & \end{array}$

Site Identifier:

Period of record:

Aquifer material:

Aquifer code: counties used here include: sequential numbers. on a continual basis.
County well numbers are assigned by the USGS to each well in the USGS Ground water site Inventory (GWSI) data base. County well numbers are sequential within each county, and wells within each county are identified by a two letter prefix. Prefixes and their respective

A unique 15-digit number that identifies each well within the GWSI database. It initially consists of the latitude and longitude of the well location, followed by a two-digit sequence number; subsequent revisions in latitude-longitude of the well are not reflected in the site identifier, but rather in its latitude and longitude. Wells that share essentially the same location are distinguished by

The period(s) of time over which water-level data were collected at the well

Lithology of the aquifer material in which the well is completed.

An eight-character code from the USGS GWSI database that indicates the primary aquifer in which the well is completed. Aquifer codes used here include:

112SAND Pleistocene-age sand deposits (undifferentiated)

112ICNC Pleistocene-age ice-contact (kame) deposits

112SDGV Pleistocene-age sand and gravel deposits (undifferentiated)

112TILL Pleistocene-age till deposits

112GLCD Pleistocene-age glaciolacustrine deposits

112KMTC Pleistocene-age kame-terrace deposits

112OTSH Pleistocene-age outwash deposits

112GRVL Pleistocene-age gravel deposits (undifferentiated)

351CMLS Upper Silurian-age Camillus Shale

355LCKP Middle Silurian-age (Niagran) Lockport Dolomite

367BKMN Lower Ordovician-age Beeckmantown Group

400BCPX Precambrian-age basement complex

BEDROCK Undifferentiated bedrock 
Aquifer type:

Well type

Well depth:

Well diameter:

Screened zone:

Physiographic region:

Climatic zone:

Average annual precipitation:

Topographic setting:

Annual water-level range:

Network:

Lowest water level:

Remarks:
Water table - Water in this aquifer is primarily under unconfined (at atmo spheric pressure) conditions.

Confined - Water in this aquifer is under confined (artesian, or greater than atmospheric pressure) conditions.

Refers to the method of well construction, as follows:

drilled - installed by conventional drilling methods such as air-rotary, hydrau lic-rotary, reverse-rotary, or cable-tool drilling. Drilled wells are generally 6 to 8 inches in diameter.

dug - large-diameter, hand-dug wells of walled, tile, or stone construction.

augered - Small-diameter (less than 4 inches) well installed with a hollowstem auger drill rig.

driven - generally refers to small-diameter (less than 2 inches) wells equipped with a well point and are hand-driven into the aquifer. May also include some 6-inch-diameter wells driven by cable-tool equipment.

Depth of completed well, in feet below land surface

Nominal inside diameter of largest casing used in well, in inches

Depth to the top and bottom of the well interval open to the aquifer, in feet below land surface.

One of the nine physiographic provinces in New York in which the well is located. (See fig. 3.)

One of the 10 climatic zones in New York in which the well is located. (See fig. 2.)

Estimated average annual precipitation near each well location. (Data from Randall, 1996).

A general description of the topographic setting of the well location.

Average annual range in water-level fluctuation in the well.

One of two networks - - "baseline" or "water management" to which the well belongs

The lowest water level recorded in the well during the period of record, in feet below land surface.

Miscellaneous information about the well or its performance, or suggestions for improvement or replacement. 
Appendix 1. Selected data for wells in the U.S. Geological Survey Federal-State cooperative observation- well network in New York, fiscal years 1995 and 1997.*

[Wells in boldface indicate reactivated wells currently funded in FY97. Average annual precipitation data from Randall (1996).]

\section{A. EASTERN NEW YORK}

\begin{tabular}{|c|c|c|c|c|c|c|c|c|c|c|}
\hline $\begin{array}{l}\text { County } \\
\text { well no. }\end{array}$ & Site no. & $\begin{array}{l}\text { Period of } \\
\text { record }\end{array}$ & $\begin{array}{l}\text { Aquifer } \\
\text { material }\end{array}$ & $\begin{array}{l}\text { Aquifer } \\
\text { code }\end{array}$ & $\begin{array}{l}\text { Aquifer } \\
\text { type }\end{array}$ & $\begin{array}{l}\text { Well } \\
\text { type }\end{array}$ & $\begin{array}{l}\text { Well } \\
\text { depth } \\
\text { (ft) }\end{array}$ & $\begin{array}{l}\text { Well } \\
\text { diam } \\
\text { (in) }\end{array}$ & $\begin{array}{l}\text { Screened } \\
\text { (open) } \\
\text { zone }\end{array}$ & $\begin{array}{l}\text { Physiographic } \\
\text { regior }\end{array}$ \\
\hline A-636 & 424114073495402 & $5 / 74-8 / 95$ & sand & 112SAND & water table & drilled & 24 & 6 & $22-24$ & $\begin{array}{l}\text { Hudson-Mohawk } \\
\text { Lowland }\end{array}$ \\
\hline A-637 & 420440073535101 & $8 / 76-8 / 95$ & $\begin{array}{l}\text { sand and } \\
\text { gravel }\end{array}$ & $112 \mathrm{ICNC}$ & confined & drilled & 198 & 6 & $193-198$ & $\begin{array}{l}\text { Hudson-Mohawk } \\
\text { Lowland }\end{array}$ \\
\hline D-492 & 420748075043101 & $\begin{array}{l}9 / 77-8 / 83 \\
10 / 84-8 / 95\end{array}$ & $\begin{array}{l}\text { shale and } \\
\text { sandstone }\end{array}$ & BEDROCK & confined & drilled & 180 & 6 & $30-180$ & Appalachian Upland \\
\hline Du-321 & 414737073563301 & $\begin{array}{l}9 / 48-4 / 50 \\
4 / 53-9 / 97\end{array}$ & shale & BEDROCK & confined & drilled & 127 & 6 & unknown & Appalachian Upland \\
\hline Du-1009 & 414128073475201 & $\begin{array}{c}10 / 65-4 / 69 \\
6 / 71-7 / 89 \\
12 / 91-9 / 93\end{array}$ & $\begin{array}{l}\text { sand and } \\
\text { gravel }\end{array}$ & $112 \mathrm{SDGV}$ & water table & augered & 27 & 2.5 & $25-27$ & Appalachian Upland \\
\hline G-1 & 422319073482001 & $12 / 45-8 / 95$ & till & $112 \mathrm{TILL}$ & water table & dug & 17 & 36 & $2-17$ & Appalachian Upland \\
\hline $\mathrm{H}-3$ & 432832074122201 & $11 / 65-8 / 95$ & sand & 112 SAND & water table & augered & 19 & 2.5 & $16-19$ & Adirondack U lands \\
\hline Mt-1 & 430141074423501 & $10 / 42-8 / 95$ & till & 112 TILL & water table & dug & 12 & 24 & $0-12$ & $\begin{array}{l}\text { Hudson-Mohawk } \\
\text { Lowland }\end{array}$ \\
\hline Oe-151 & 433112075091501 & $\begin{array}{c}7 / 26-8 / 45 \\
\text { 10/48-present }\end{array}$ & sand & 112SAND & water table & dug & 31 & 36 & $0-31$ & Adirondack U \\
\hline Oe-766 & 433012075134202 & $11 / 68-8 / 95$ & sand & 112SAND & water table & driven & 33 & 6 & open end & Adirondack U lands \\
\hline P-609 & 412450073413101 & $\begin{array}{l}1 / 35-9 / 45 \\
9 / 50-8 / 95\end{array}$ & till & $112 \mathrm{TILL}$ & water table & dug & 16.1 & 36 & $0-16$ & New England Upland \\
\hline Re-700 & 423834073391001 & $9 / 54-8 / 95$ & $\begin{array}{l}\text { sand and } \\
\text { gravel }\end{array}$ & $112 \mathrm{SDGV}$ & water table & dug & 15.9 & 48 & $0-16$ & New England Upland \\
\hline Re-703 & 423534073423401 & $10 / 82-8 / 95$ & $\begin{array}{l}\text { sand and } \\
\text { gravel }\end{array}$ & 112SDGV & confined & drilled & 80 & 6 & $78-80$ & New England Upland \\
\hline Ro-18 & 411802073593001 & $\begin{array}{c}7 / 49-9 / 90 \\
11 / 91-9 / 93\end{array}$ & granite & 400BCPX & confined & drilled & 60 & 6 & $53-60$ & New England Upland \\
\hline St-40 & 444904074455201 & $5 / 53-8 / 95$ & sand & 112SAND & water table & dug & 11.3 & 36 & $0-11.3$ & $\begin{array}{l}\text { St. Lawrence } \\
\text { Lowland }\end{array}$ \\
\hline St-404 & 445216074593001 & $\begin{array}{l}6 / 58-11 / 64 \\
11 / 85-8 / 95\end{array}$ & dolomite & 367BKMN & confined & drilled & 178.9 & 6 & $54-179$ & $\begin{array}{l}\text { St. Lawrence } \\
\text { Lowland }\end{array}$ \\
\hline Sa-529 & 430327073475401 & $\begin{array}{l}5 / 49-11 / 61 \\
8 / 64-8 / 95\end{array}$ & dolomite & BEDROCK & confined & drilled & 288 & 6 & $189-288$ & $\begin{array}{l}\text { Hudson-Mohawk } \\
\text { Lowland }\end{array}$ \\
\hline Sa-1072 & 430013073370401 & $7 / 59-8 / 95$ & sand & 112SAND & water table & drilled & 24 & 6 & $21-24$ & $\begin{array}{l}\text { Hudson-Mohawk } \\
\text { Lowland }\end{array}$ \\
\hline Sa-1100 & 425242073473201 & 4/83-present & $\begin{array}{l}\text { sand and } \\
\text { gravel }\end{array}$ & $112 \mathrm{ICNC}$ & confined & drilled & 180 & 6 & open end & $\begin{array}{l}\text { Hudson-Mohawk } \\
\text { Lowland }\end{array}$ \\
\hline $\mathrm{Sn}-363$ & 424910073591401 & $6 / 60-8 / 95$ & $\begin{array}{l}\text { sand and } \\
\text { gravel }\end{array}$ & $112 \mathrm{SDGV}$ & water table & drilled & 57 & 6 & open end & $\begin{array}{l}\text { Hudson-Mohawk } \\
\text { Lowland }\end{array}$ \\
\hline U-204 & 414425074213601 & $\begin{array}{l}10 / 54-9 / 87 \\
1 / 90-8 / 95\end{array}$ & till & 112TILL & water table & drilled & 67 & 8 & open end? & Appalachian Upland \\
\hline $\mathrm{U}-405$ & 414948074035101 & $\begin{array}{c}10 / 64-7 / 65 \\
3 / 66-12 / 74 \\
4 / 76-8 / 95\end{array}$ & sand & 112SAND & water table & augered & 36 & 2.5 & $34-36$ & $\begin{array}{l}\text { Hudson-Mohawk } \\
\text { Lowland }\end{array}$ \\
\hline W-533 & 431030073192101 & $3 / 74-8 / 95$ & $\begin{array}{l}\text { sand and } \\
\text { gravel }\end{array}$ & 112SDGV & water table & drilled & 16 & 6 & open & New England Upland \\
\hline We-3 & 411421073481201 & $\begin{array}{l}4 / 34-9 / 37 \\
4 / 38-8 / 45 \\
3 / 51-8 / 95\end{array}$ & sand & 112SAND & water table & dug & 18.2 & 36 & $0-18.2$ & New England Upland \\
\hline
\end{tabular}

* Fiscal year (FY) is from October 1 through September 30; thus, FY 1995 began on October 1, 1994. 
Appendix 1. Selected well data for U.S. Geological Survey Federal-State cooperative observation- well network in New York, fiscal years 1995 and 1997 (continued)

\section{A. EASTERN NEW YORK}

\begin{tabular}{|c|c|c|c|c|c|c|c|}
\hline $\begin{array}{l}\text { County } \\
\text { well no. }\end{array}$ & Climatic Zone & $\begin{array}{l}\text { Avg. } \\
\text { annual } \\
\text { precip } \\
\text { (inches). }\end{array}$ & $\begin{array}{l}\text { Topo- } \\
\text { graphic } \\
\text { setting }\end{array}$ & $\begin{array}{l}\text { Annual } \\
\text { water- } \\
\text { level } \\
\text { range }\end{array}$ & Network & $\begin{array}{l}\text { Lowest } \\
\text { water } \\
\text { level } \\
\text { (ft) }\end{array}$ & Remarks \\
\hline A-636 & Hudson Valley & 38 & upland plain & 7 & baseline & 13.13 & $\begin{array}{l}\text { Replaced A-635 in 1965. Discontinued in 1995. Reacti- } \\
\text { vated in } 1997 .\end{array}$ \\
\hline A-637 & Hudson Valley & 40 & upland plain & 14 & $\begin{array}{l}\text { water } \\
\text { mgmt. }\end{array}$ & 132.44 & Confined channel aquifer. Discontinued in 1995. \\
\hline D-492 & Eastern Plateau & 45 & hilltop & $60+$ & baseline & 180 & $\begin{array}{l}\text { Affected by pumping? Responds rapidly to recharge. } \\
\text { Discontinued in } 1995 .\end{array}$ \\
\hline Du-321 & Hudson Valley & 38 & hilltop & 8 & baseline & 73.85 & $\begin{array}{l}\text { Casing depth unknown. } \\
\text { Responds to semidiurnal earth tides ( } 0.05 \text { feet }) \text {. }\end{array}$ \\
\hline Du-1009 & Hudson Valley & 40 & valley floor & 9 & baseline & 20.6 & $\begin{array}{l}\text { Discontinued in 1993. Stream control? Reactivated in } \\
1997 .\end{array}$ \\
\hline G-1 & Hudson Valley & 36 & upland plain & 10 & baseline & 15.56 & Discontinued in 1995. \\
\hline $\mathrm{H}-3$ & Northern Plateau & 46 & valley terrace & 9 & baseline & 16.19 & $\begin{array}{l}\text { Lowest water level below top of screen. } \\
\text { Discontinued in } 1995\end{array}$ \\
\hline Mt-1 & Mohawk Valley & 40 & upland & 3 & baseline & 9.99 & Discontinued in 1995. \\
\hline Oe-151 & Northern Plateau & 48 & upland plain & 19 & baseline & 30.31 & $\begin{array}{l}\text { Federal network well until } 1996 \text {. Lowest water level } \\
\text { within } 1 \text { foot of well bottom. }\end{array}$ \\
\hline Oe-766 & Northern Plateau & 48 & upland plain & 9 & baseline & 23.58 & $\begin{array}{l}\text { Discontinued in 1995. Candidate replacement well } \\
\text { for Oe-151. }\end{array}$ \\
\hline P-609 & Hudson Valley & 48 & hillside & 16 & baseline & dry & Well goes dry frequently in fall. Discontinued in 1995. \\
\hline $\operatorname{Re}-700$ & Hudson Valley & 36 & upland & 6 & baseline & 15.49 & $\begin{array}{l}\text { Lowest water level within } 1 / 2 \text { foot of bottcm. } \\
\text { Discontinued in } 1995\end{array}$ \\
\hline $\operatorname{Re}-703$ & Hudson Valley & 36 & upland plain & 9 & $\begin{array}{l}\text { water } \\
\text { mgmt. }\end{array}$ & 41.93 & $\begin{array}{l}\text { Replaced Re-701 in } 1982 . \text { May be affected by pumping. } \\
\text { Discontinued in } 1995 .\end{array}$ \\
\hline Ro-18 & Hudson Valley & 48 & hillside & 18 & baseline & 33 & Discontinued in 1993. \\
\hline St-40 & St. Lawrence & 33 & plain & 6 & baseline & 9.38 & Discontinued in 1995. Reactivated in 1997. \\
\hline St-404 & St. Lawrence & 33 & plain & 5 & baseline & 16.77 & Discontinued in 1995. \\
\hline Sa-529 & Hudson Valley & 37 & upland plain & 16 & baseline & 56.2 & $\begin{array}{l}\text { Water level affected by earthquakes and distant pumping. } \\
\text { Discontinued in } 1995 \text {. }\end{array}$ \\
\hline Sa-1072 & Hudson Valley & 36 & upland plain & 8 & $\begin{array}{l}\text { water } \\
\text { mgmt. }\end{array}$ & & $\begin{array}{l}\text { Well filled in to } 19.6 \text { feet. Affected by nearby pumping. } \\
\text { Discontinued in } 1995 \text {. }\end{array}$ \\
\hline Sa-1100 & Hudson Valley & 36 & upland plain & 85 & $\begin{array}{l}\text { water } \\
\text { mgmt. }\end{array}$ & 107.38 & $\begin{array}{l}\text { Well in cone of depression of nearby supply well. } \\
\text { Suggest replacement with another well in Clifton Park. }\end{array}$ \\
\hline$S n-363$ & Mohawk Valley & 36 & valley floor & 27 & $\begin{array}{l}\text { water } \\
\text { mgmt. }\end{array}$ & 31.27 & $\begin{array}{l}\text { Located within municipal well field cone cf depression. } \\
\text { Also affected by stage of Mohawk River. Discontinued in } \\
\text { 1995. Recommend replacement with I- } 890 \text { loop well. }\end{array}$ \\
\hline U-204 & Eastern Plateau & 45 & Alluvial fan & 10 & baseline & 26.9 & $\begin{array}{l}\text { Filled-in to } 45.6 \text { feet. Aquifer and open interval unknown. } \\
\text { Suggest geophysical logging to confirm aquifer and } \\
\text { construction. Discontinued in } 1995 \text {. }\end{array}$ \\
\hline $\mathrm{U}-405$ & Hudson Valley & 42 & valley floor & 7 & baseline & 20.7 & $\begin{array}{l}\text { Filled-in to } 33.3 \text { feet. Installed within a pre-existing dug } \\
\text { well. Discontinued in } 1995 \text {. }\end{array}$ \\
\hline W-533 & Hudson Valley & 38 & valley floor & 4 & baseline & 7.77 & $\begin{array}{l}\text { Filled-in to } 15.2 \text { feet. Replaced nearby well W-532 in } \\
\text { 1974. Discontinued in } 1995 .\end{array}$ \\
\hline We-3 & Hudson Valley & 47 & hillside & 15 & baseline & dry & $\begin{array}{l}\text { Located } 500 \mathrm{ft} \text { from New Croton Reservoi. Frequently } \\
\text { goes dry in autumn. Discontinued in } 1995 \text {. Filled-in } \\
\text { to } 17 \text { feet. }\end{array}$ \\
\hline
\end{tabular}


Appendix 1. Selected data for wells in the U.S. Geological Survey Federal-State cooperative observation- well network in New York, fiscal years 1995 and 1997.*

[ft, feet, in, inches, mi, mile. Wells in boldface indicate reactivated wells funded in Fiscal Year 97. Average annual precipitation data from Randall (1996).]

\section{B. WESTERN NEW YORK}

\begin{tabular}{|c|c|c|c|c|c|c|c|c|c|c|}
\hline $\begin{array}{l}\text { County } \\
\text { well no. }\end{array}$ & Site no. & $\begin{array}{l}\text { Period of } \\
\text { record }\end{array}$ & $\begin{array}{l}\text { Aquifer } \\
\text { material }\end{array}$ & $\begin{array}{l}\text { Aquifer } \\
\text { code }\end{array}$ & $\begin{array}{l}\text { Aquifer } \\
\text { type }\end{array}$ & $\begin{array}{l}\text { Well } \\
\text { type }\end{array}$ & $\begin{array}{l}\text { Well } \\
\text { depth } \\
(\mathrm{ft})\end{array}$ & $\begin{array}{c}\text { Well } \\
\text { diam } \\
\text { (in) }\end{array}$ & $\begin{array}{l}\text { Screened } \\
\text { (open) } \\
\text { zone }\end{array}$ & $\begin{array}{c}\text { Physiographic } \\
\text { Region }\end{array}$ \\
\hline $\mathrm{Bm}-100$ & 420646075531201 & $\begin{array}{c}10 / 46-7 / 55 \\
4 / 66-8 / 95\end{array}$ & $\begin{array}{l}\text { sand- } \\
\text { gravel }\end{array}$ & $112 \mathrm{SDGV}$ & water table & drilled & 52 & 6 & $40-45$ & Appalachian Upland \\
\hline Bm-121 & 420657075583501 & $3 / 47-8 / 95$ & sand & $112 \mathrm{SDGV}$ & water table & drilled & 53 & 6 & open end & Appalachian Upland \\
\hline $\mathrm{Bm}-128$ & 421138075511301 & $9 / 80-8 / 95$ & $\begin{array}{l}\text { sand- } \\
\text { gravel }\end{array}$ & $112 \mathrm{ICNC}$ & water table & drilled & 53 & 6 & $48.5-53$ & Appalachian Upland \\
\hline $\mathrm{Bm}-129$ & 421157075535401 & $11 / 85-8 / 95$ & shale & BEDROCK & confined & drilled & 252 & 6 & $?$ & Appalachian Upland \\
\hline Ct-121 & 420530078445201 & 9/50-present & $\begin{array}{l}\text { sand- } \\
\text { gravel }\end{array}$ & $112 \mathrm{SDGV}$ & confined & drilled & 53 & 6 & open end & Appalachian Upland \\
\hline $\mathrm{Cy}-7$ & 424158076251901 & $12 / 65-8 / 95$ & gravel & $112 \mathrm{SDGV}$ & water table & drilled & 28 & 2.5 & $26-28$ & Appalachian Upland \\
\hline $\mathrm{Cu}-5$ & 420326079295801 & $5 / 49-8 / 95$ & till & $112 \mathrm{TILL}$ & water table & dug & 33 & 36 & $0-33$ & Appalachian Upland \\
\hline $\mathrm{Cu}-10$ & 420815079121401 & $\begin{array}{l}11 / 39-9 / 43 \\
8 / 46-8 / 95\end{array}$ & $\begin{array}{l}\text { sand- } \\
\text { gravel }\end{array}$ & $112 \mathrm{GLCD}$ & confined & drilled & 232 & $12 / 10$ & $130-144$ & Appalachian Upland \\
\hline $\mathrm{Cu}-104$ & 420748079062701 & $\begin{array}{c}9 / 62-10 / 62 \\
3 / 83-8 / 95\end{array}$ & $\begin{array}{l}\text { sand- } \\
\text { gravel }\end{array}$ & $112 \mathrm{GLCD}$ & confined & drilled & 79 & 6 & $69-79$ & Appalachian Upland \\
\hline $\mathrm{Cm}-46$ & 420829076484801 & 10/55-present & $\begin{array}{l}\text { sand- } \\
\text { gravel }\end{array}$ & $112 \mathrm{SDGV}$ & water table & drilled & 34 & 6 & open end & Appalachian Upland \\
\hline $\mathrm{Cn}-12$ & 421556075281602 & 4/75-present & gravel & $112 \mathrm{SDGV}$ & water table & drilled & 13 & 6 & open end & Appalachian Upland \\
\hline $\mathrm{Cn}-13$ & 423849075315701 & $4 / 84-4 / 94$ & $\begin{array}{l}\text { sand- } \\
\text { gravel }\end{array}$ & $112 \mathrm{KMTC}$ & confined & drilled & 125 & 6 & $121-125$ & Appalachian Upland \\
\hline C-102 & 423541076114701 & 10/75-present & gravel & 112OTSH & water table & driven & 45 & 1.25 & $43-45$ & Appalachian Upland \\
\hline M-178 & 430056075354102 & $4 / 75-8 / 95$ & gravel & 112GRVL & water table & drilled & 16 & 6 & open end & Appalachian Upland \\
\hline $\mathrm{Ni}-69$ & 430655079022001 & $10 / 58-8 / 95$ & dolomite & $355 \mathrm{LCKP}$ & confined & drilled & 36 & $8 / 6$ & $17-36$ & Erie-Ontario Lowland \\
\hline Ni-70 & 431308078544501 & 8/72-present & sand & 112SAND & water table & dug & 24 & 48 & $0-24$ & Erie-Ontario Lowland \\
\hline Ot-900 & 425840077133901 & $5 / 55-8 / 95$ & shale & 351CMLS & confined & drilled & 139 & 6 & $11-139$ & Appalachian Upland \\
\hline Og-23 & 424136075025101 & $5 / 53-8 / 95$ & till & 112TILL & water table & dug & 15 & 36 & $0-15$ & Appalachian Upland \\
\hline $\mathrm{Sb}-472$ & 422445077203301 & 11/65-present & grave1 & $112 \mathrm{SDGV}$ & water table & driven & 18 & 2.5 & $16-18$ & Appalachian Upland \\
\hline $\mathrm{Sb}-473$ & 420811077021501 & 9/89-8/95 & $\begin{array}{l}\text { sand- } \\
\text { gravel }\end{array}$ & 112OTSH & water table & drilled & 83 & 6 & open end & Appalachian Upland \\
\hline Wo-1 & 423739077595501 & 11/42-present & till & $112 \mathrm{TILL}$ & water table & driven & 15 & 2 & $13-15$ & Appalachian Upland \\
\hline Wo-4 & 423743078070802 & 5/74-present & sand & 112 SAND & water table & drilled & 20 & 6 & open end & Appalachian Upland \\
\hline
\end{tabular}

* Fiscal year (FY) is from October 1 through September 30; thus, FY 1995 began on October 1, 1994. 
Appendix 1. Selected well data for U.S. Geological Survey Federal-State cooperative observation- well network in New York, fiscal years 1995 and 1997 (continued)

\section{B. WESTERN NEW YORK}

\begin{tabular}{|c|c|c|c|c|c|c|c|}
\hline $\begin{array}{l}\text { County } \\
\text { well no. }\end{array}$ & Climatic Zone & $\begin{array}{l}\text { Avg. } \\
\text { annual } \\
\text { precip. } \\
\text { (inches) }\end{array}$ & $\begin{array}{l}\text { Topo- } \\
\text { graphic } \\
\text { setting }\end{array}$ & $\begin{array}{c}\text { Annual } \\
\text { water- } \\
\text { level } \\
\text { range }\end{array}$ & Network & $\begin{array}{c}\text { Lowest } \\
\text { water } \\
\text { level } \\
\text { (ft) }\end{array}$ & Remarks \\
\hline
\end{tabular}

\begin{tabular}{|c|c|c|c|c|c|c|c|}
\hline $\mathrm{Bm}-100$ & Eastern Plateau & 38 & valley floor & 4 & $\begin{array}{l}\text { baseline/ } \\
\text { mgmt }\end{array}$ & 13.2 & Affected by nearby pumping? Discontinued in 1995 . \\
\hline Bm-121 & Eastern Plateau & 38 & valley floor & 24 & mgmt & 29.4 & $\begin{array}{l}\text { Water level affected by high stages of Susquehanna River and } \\
\text { by pumping from wellfield } 1100 \mathrm{ft} \text { south. Discontinued in } \\
1995 \text {; reactivated in } 1997 .\end{array}$ \\
\hline $\mathrm{Bm}-128$ & Eastern Plateau & 36 & valley floor & 13 & $\begin{array}{l}\text { baseline/ } \\
\text { mgmt }\end{array}$ & 32.8 & $\begin{array}{l}\text { Water level may be affected by school supply well } 300 \mathrm{ft} \text { west } \\
\text { and public supply well to the east. Discontinued in } 1995 \text {. }\end{array}$ \\
\hline Bm-129 & Eastern Plateau & 36 & hillside & 9 & baseline & 75.8 & Length of open bore unknown. Discontinued in 1995. \\
\hline Ct-121 & Western Plateau & 44 & upland valley & 7 & baseline & 34.8 & Water levels affected by local pumping 1969-79. \\
\hline $\mathrm{Cy}-7$ & Central Lakes & 38 & valley floor & 8 & baseline & 25 & $\begin{array}{l}\text { Lowest water level within } 1 \mathrm{ft} \text { of top of screen. Discontinued } \\
\text { in } 1995 .\end{array}$ \\
\hline $\mathrm{Cu}-5$ & Great Lakes & 44 & upland & 9 & baseline & 9.4 & $\begin{array}{l}\text { NYSDEC owned. Discontinued in } 1995 \text {. Poor record except } \\
\text { for digital recorder record, 4/90-9/92. }\end{array}$ \\
\hline $\mathrm{Cu}-10$ & Great Lakes & 44 & valley floor & 38 & mgmt & 66.6 & $\begin{array}{l}\text { Affected by pumping from municipal well field. Long period } \\
\text { of record. Discontinued in 1995; reactivated in 1997. Within } \\
\text { well field. }\end{array}$ \\
\hline $\mathrm{Cu}-104$ & Great Lakes & 44 & valley floor & 24 & $\mathrm{mgmt}$ & 21.3 & $\begin{array}{l}\text { Water level reflects pumping from Jamestown wellfield \& } \\
\text { stage of nearby Conewango Creek. Discontinued in } 1995 .\end{array}$ \\
\hline $\mathrm{Cm}-46$ & Western Plateau & 34 & valley floor & 7 & baseline & 26.3 & $\begin{array}{l}\text { Water level affected by stage of Newtown Creek. Federal } \\
\text { network well, in } 1997 .\end{array}$ \\
\hline Cn-12 & Eastern Plateau & 42 & valley floor & 9 & baseline & 11.8 & $\begin{array}{l}\text { Replaced nearby well Cn-11 (10/65-9/72) in } 1974 \text {. Lowest } \\
\text { water level close to bottom of well. } 0.5 \text { mi soytheast of } \\
\text { Susquehanna River. }\end{array}$ \\
\hline $\mathrm{Cn}-13$ & Eastern Plateau & 40 & valley floor & 6 & baseline & 10.17 & $\begin{array}{l}\text { Installed in } 1980 \text { as observation well for Statewide network. } \\
\text { Water levels may reflect barometric effects and (or) slight } \\
\text { pumping effects from nearby domestic well. Discontinued in } \\
\text { 1994. Suggest reactivation. }\end{array}$ \\
\hline C-102 & Eastern Plateau & 42 & valley floor & 11 & mgmt & 14.5 & $\begin{array}{l}\text { Too close to well field? Baseline well is needed in this primary } \\
\text { aquifer. This well replaced C-19 (2/47-5/76). }\end{array}$ \\
\hline M-178 & Eastern Plateau & 40 & valley floor & 8 & baseline & 10.97 & Replaced we11 M-177 (10/65-9/73) in 1974. L 'scontinued 1995 \\
\hline Ni-69 & Great Lakes & 33 & plain & 6 & baseline & 22.3 & Open to confined and unconfined zones. Discontinued in 1995 \\
\hline $\mathrm{Ni}-70$ & Great Lakes & 32 & plain & 13 & baseline & 13.88 & Federal network well in 1997. \\
\hline Ot-900 & Central Lakes & 32 & plain & 7 & baseline & +4.4 & $\begin{array}{l}\text { Artesian we1l; water level always above land surface. Casing is } \\
11.6 \mathrm{ft} \text { above surface. Discontinued in } 1995 \text {. }\end{array}$ \\
\hline Og-23 & Eastern Plateau & 41 & upland & 10 & baseline & 12.66 & $\begin{array}{l}\text { Good annual response to precipitation. No long-term changes } \\
\text { in storage noted. Discontinued in } 1995 \text {. }\end{array}$ \\
\hline Sb-472 & Western Plateau & 34 & valley floor & 7 & baseline & 10.8 & $\begin{array}{l}\text { Good annual response to precipitation. No long-term changes } \\
\text { in storage noted. Screen partly filled in; well depth } 17 \mathrm{ft} \text {. }\end{array}$ \\
\hline Sb-473 & Western Plateau & 33 & valley floor & 8 & baseline & 9.42 & $\begin{array}{l}\text { Water levels affected by stage of Chemung River. } \\
\text { Discontinued in } 1995 \text {. }\end{array}$ \\
\hline Wo-1 & Western Plateau & 33 & upland & 13 & baseline & dry & $\begin{array}{l}\text { Went dry for the month of December 1964. NYSDEC owned. } \\
\text { Discontinued in } 1995 .\end{array}$ \\
\hline Wo-4 & Western Plateau & 37 & upland & 7 & baseline & 14 & Replaces well Wo-2 (11/65-5/74). \\
\hline
\end{tabular}


Appendix 2. Ten-year hydrographs (1986-96) of water levels at 46 observation wells in the U.S. Geological Survey Federal-State Cooperative observation-well network in upstate New York, 1995 and 1997 , and boxplots showing median monthly water levels and monthly percentile statistics (in alphabetical order by county)

A. Wells in Eastern New York

Fig. A-1 - A-636, Albany County; A-637, Albany County; D-992, Delaware County; Du-321, Dutchess County;

Fig. A-2- Du-1009, Dutchess County; G-1, Greene County; H-3, Hamilton County; Mt-1, Montgomery County

Fig. A-3- Oe-151, Oneida County; Oe-766, Oneida County; P-609, Putnam County; Re-700, Rensselaer Co'nnty

Fig. A-4 Re-703, Rensselaer County; Ro-18, Rockland County; St-40, St. Lawrence County; St-404, St. Lawrence County

Fig. A-5- Sa-529, Saratoga County; Sa-1072, Saratoga County; Sa-1100, Saratoga County; Sn-363, Schenectady County

Fig. A-6- U-204, Ulster County; U-405, Ulster County; W-533, Washington County; We-3, Westchester Cornty

B. Wells in Western New York

Fig. B-1 - Bm-100, Broome County; Bm-121, Broome County; Bm-128, Broome County; Bm-129, Broome County

Fig. B-2- Ct-121, Cattaraugus County; Cy-7, Cayuga County; Cu-5, Chautaugua County; Cu-10, Chautaugra County

Fig. B-3- Cu-104, Chautaugua County; Cm-46, Chemung County; Cn-12, Chenango County; Cm-13, Chenango County

Fig. B-4 C-102, Cortland County; M-178, Madison County; Ni-69, Niagara County; Ni-70, Niagara County

Fig. B-5- Ot-900, Ontario County; Og-23, Otsego County; Sb-472, Steuben County; Sb-473, Steuben Courty;

Fig. B-6- Wo-1, Wyoming County; Wo-4, Wyoming County 


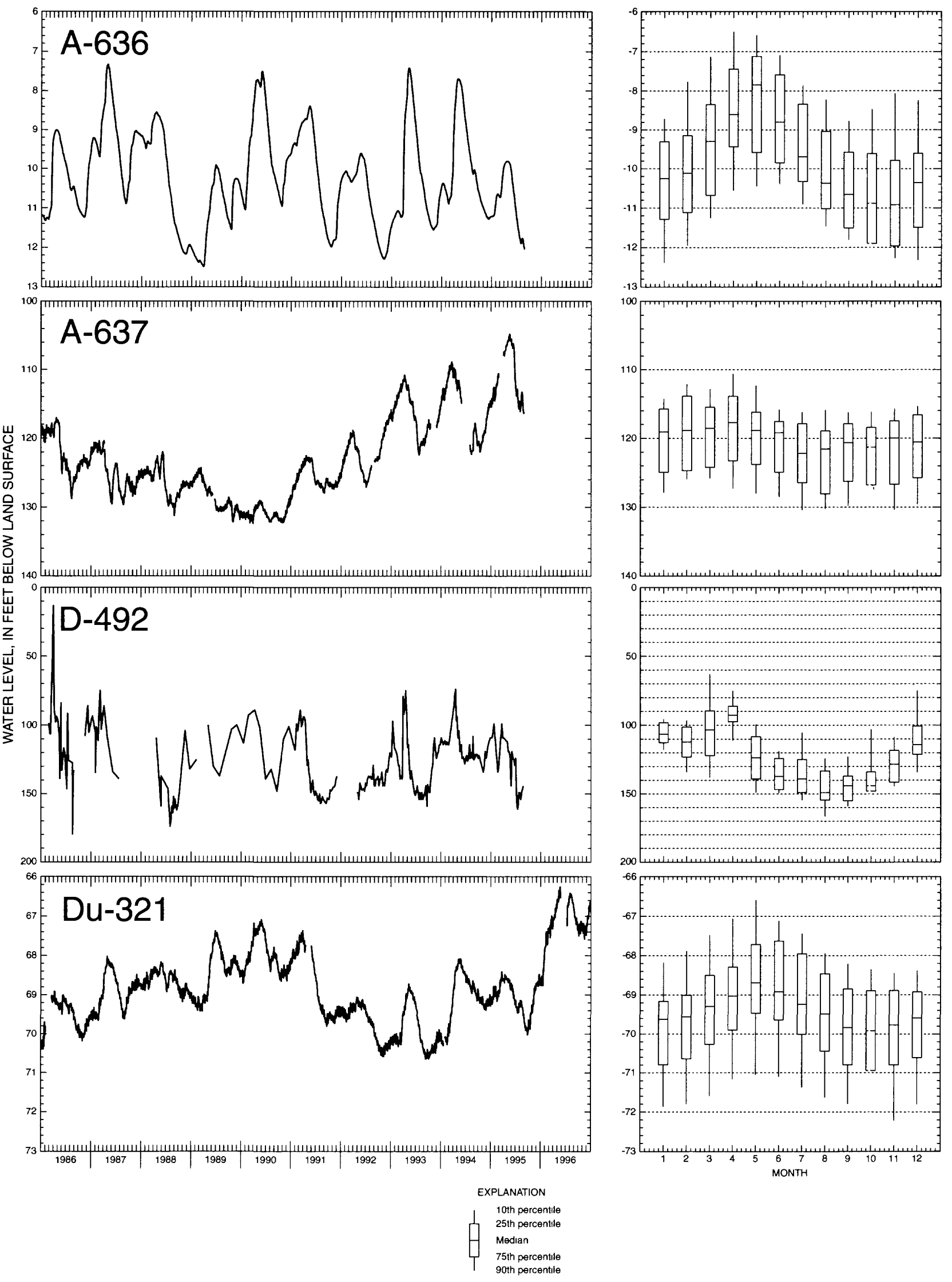

Figure A1. Ten-year hydrographs (1986-96) and boxplots showing median monthly water levels and monthly percentile statistics for observation wells A636 (Albany County), A637 (Albany County), D492 (Delaware County), and Du 321 (Dutchess County). 

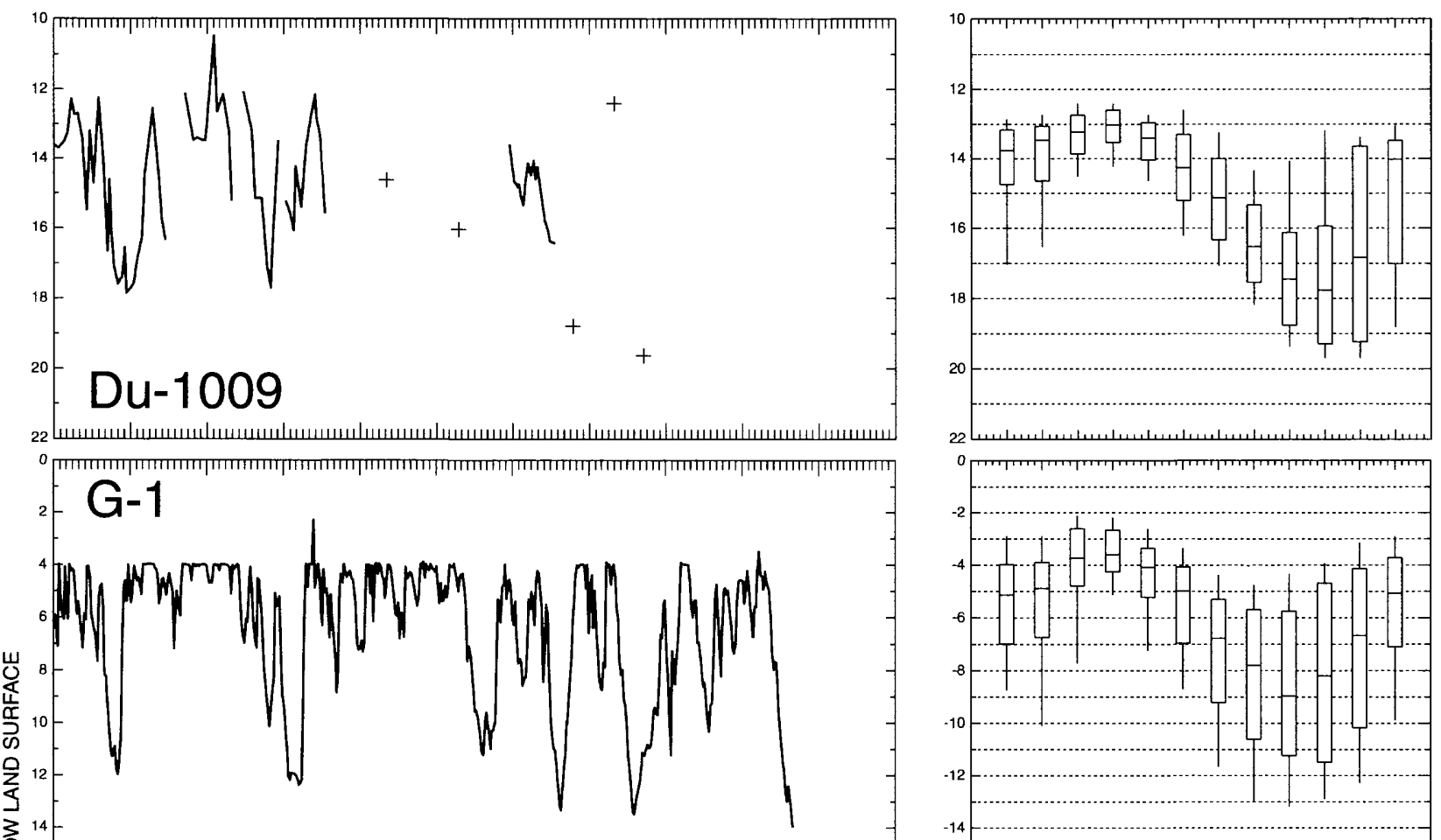

\section{,}

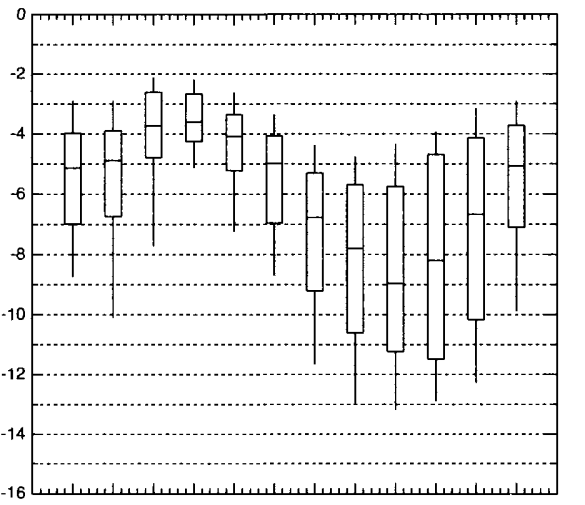

لبر

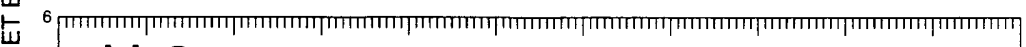
岩

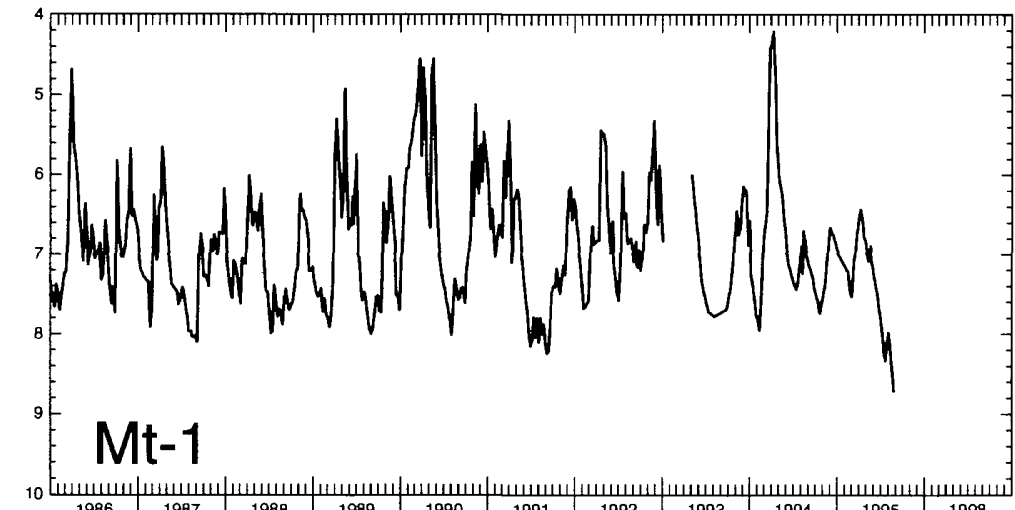

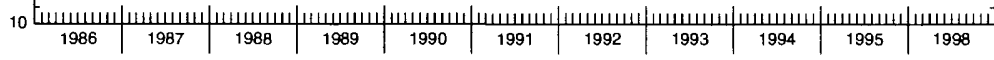
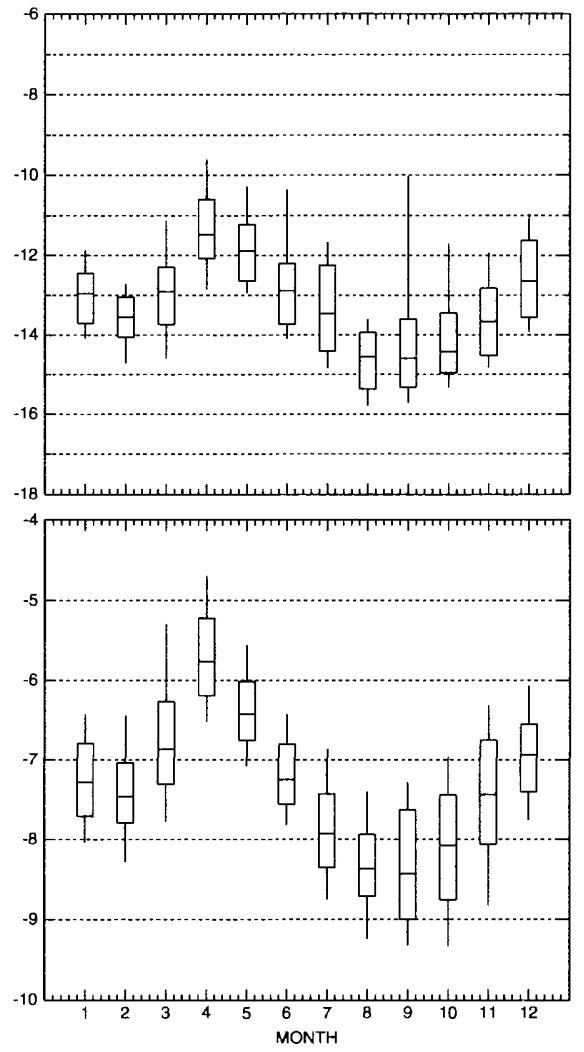

$$
\begin{aligned}
& \text { EXPLANATION } \\
& \begin{array}{|l}
1 \text { Oth percentile } \\
25 \text { th percentile } \\
\text { Median } \\
75 \text { th percentile } \\
90 \text { th percentile }
\end{array}
\end{aligned}
$$

Figure A2. Ten-year hydrographs (1986-96) and boxplots showing median monthly water levels and monthly percentile statistics for observation wells Du-1009 (Dutchess County), G-1 (Greene County), H-3 (Hamilton County), and Mt-1 (Montgomery County). 

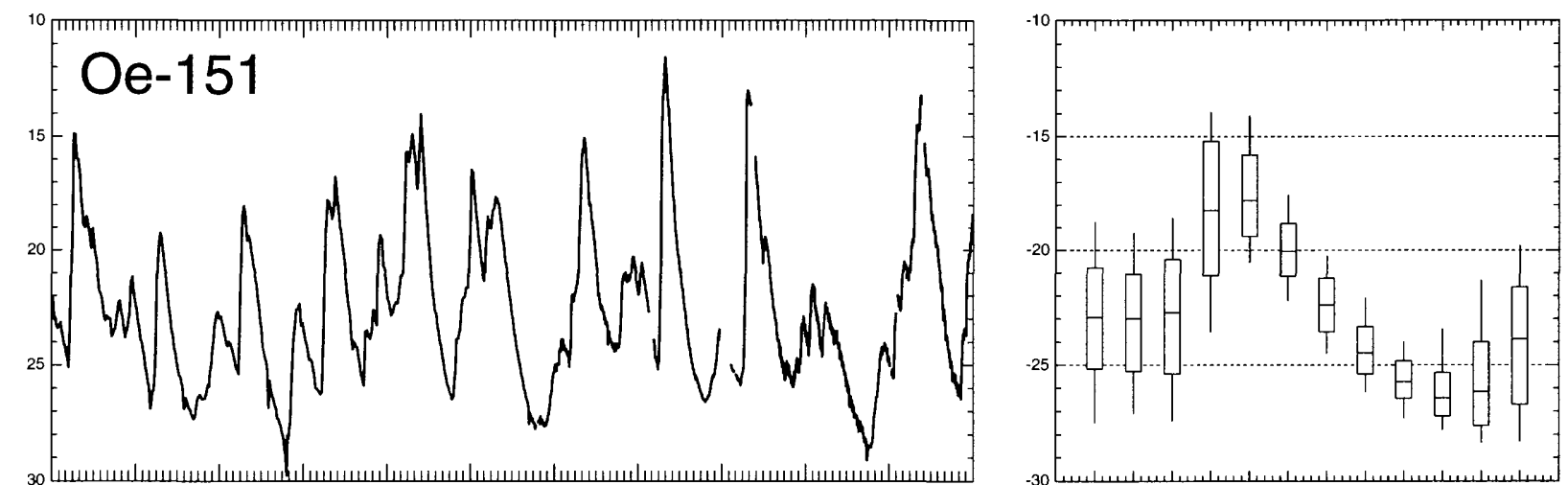

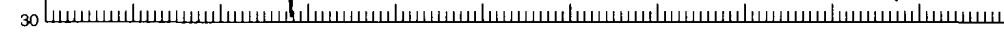

\section{Oe-766}

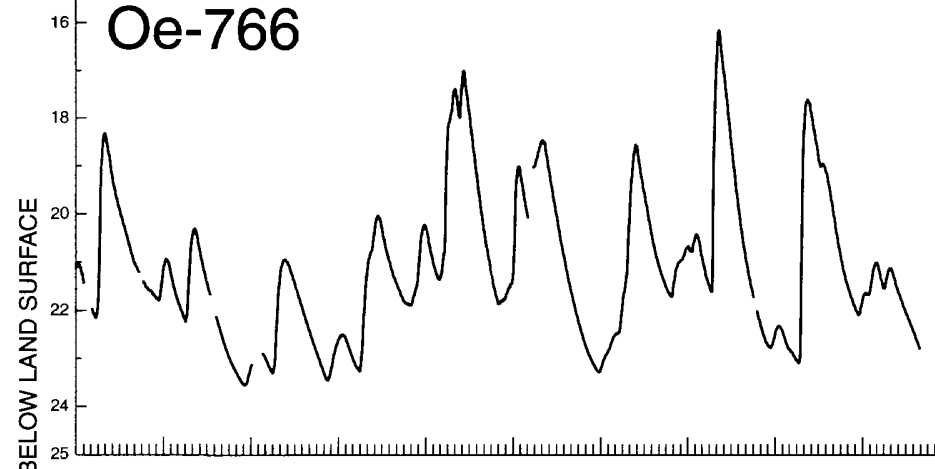

بر ${ }_{25}$

㟧

P-609

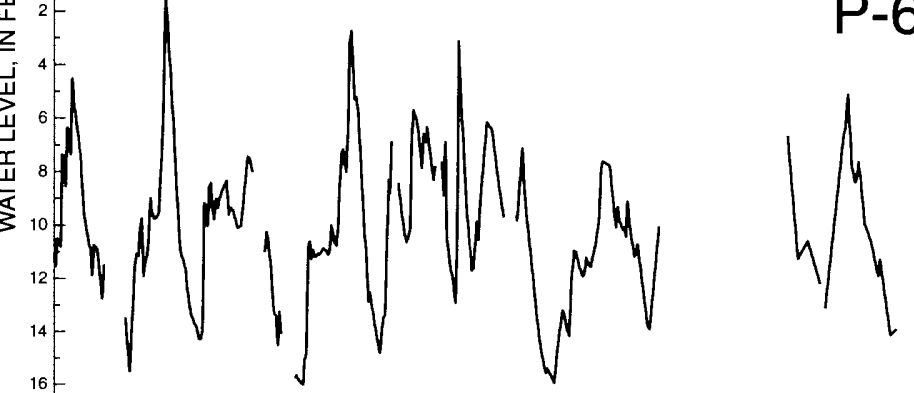

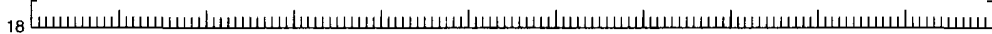

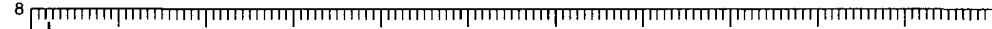

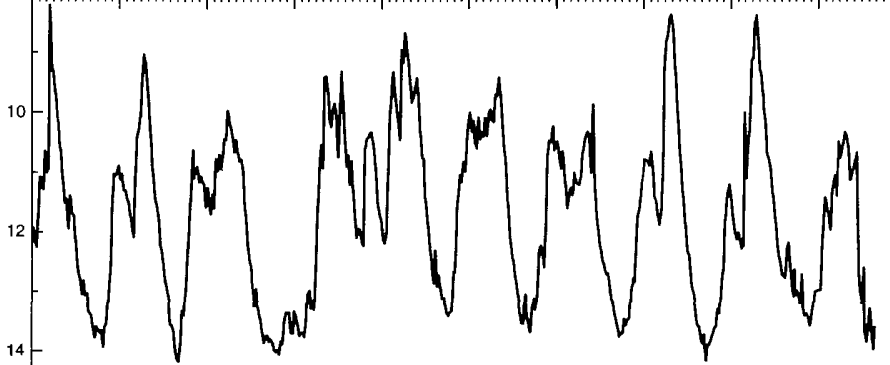

$\operatorname{Re}-700$

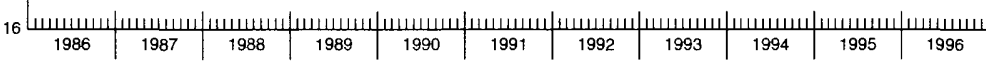

$$
\begin{array}{|l}
\text { EXPLANATION } \\
\begin{array}{l}
\text { 10th percentile } \\
25 \text { th percentlle } \\
\text { Median } \\
75 \text { th percentlle } \\
90 \text { th percentile }
\end{array}
\end{array}
$$

Figure A3. Ten-year hydrographs (1986-96) and boxplots showing median monthly water levels and monthly percentile statistics for observation wells Oe-151 (Oneida County), Oe-766 (Oneida County), P-609 (Putnam County), and Re-700 (Rensselaer County). 

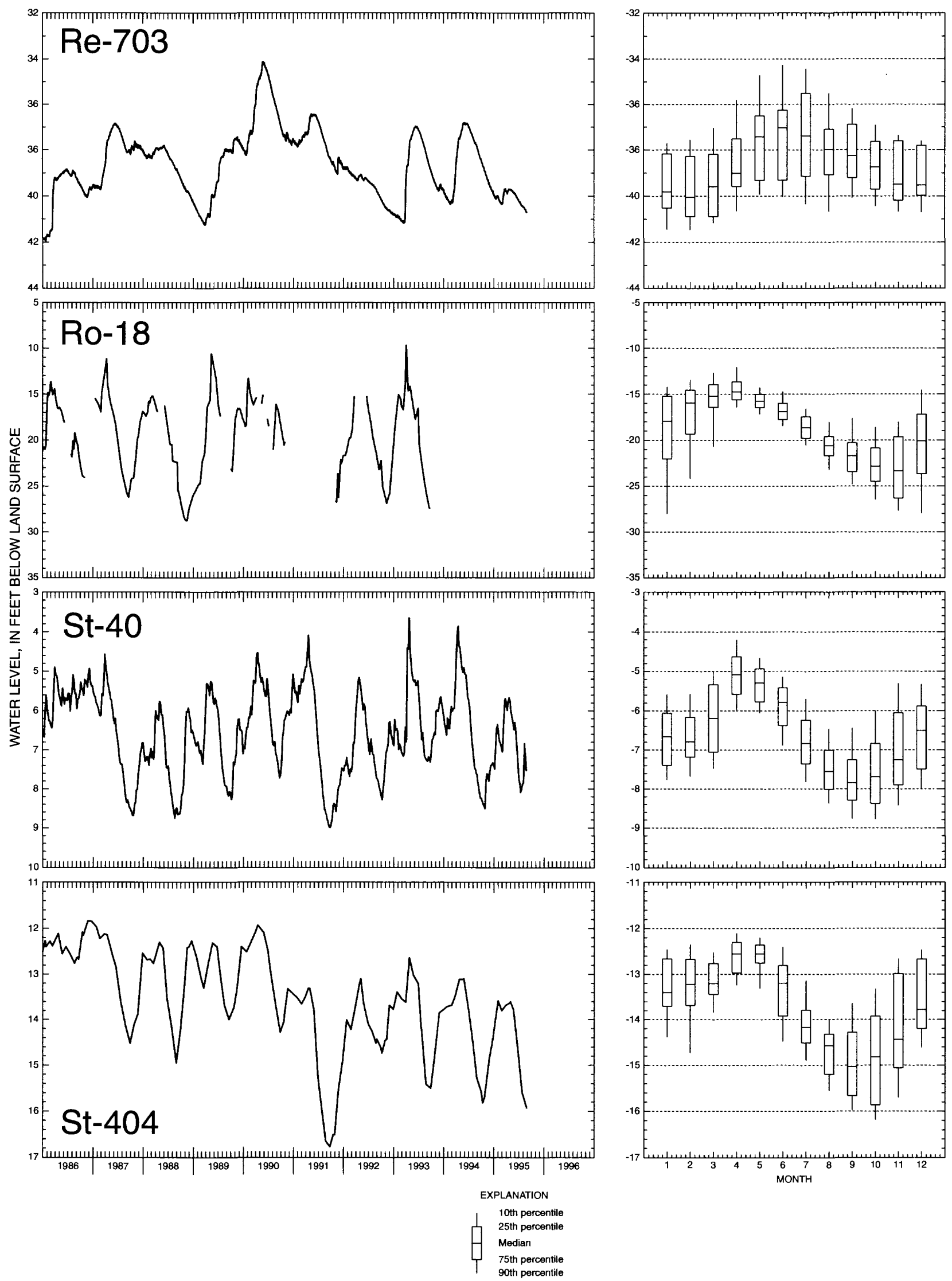

Figure A4. Ten-year hydrograph (1986-96) and boxplots showing median monthly water levels and monthly percentile statistics for observation wells Re-703 (Rensselaer County), Ro-18 (Rockland County), St-40 (St. Lawrence County), and St-404 (St. Lawrence County).

28 Evaluation of the Federal-State Cooperative Observation Well Network in Upstate New York, 1995-97 


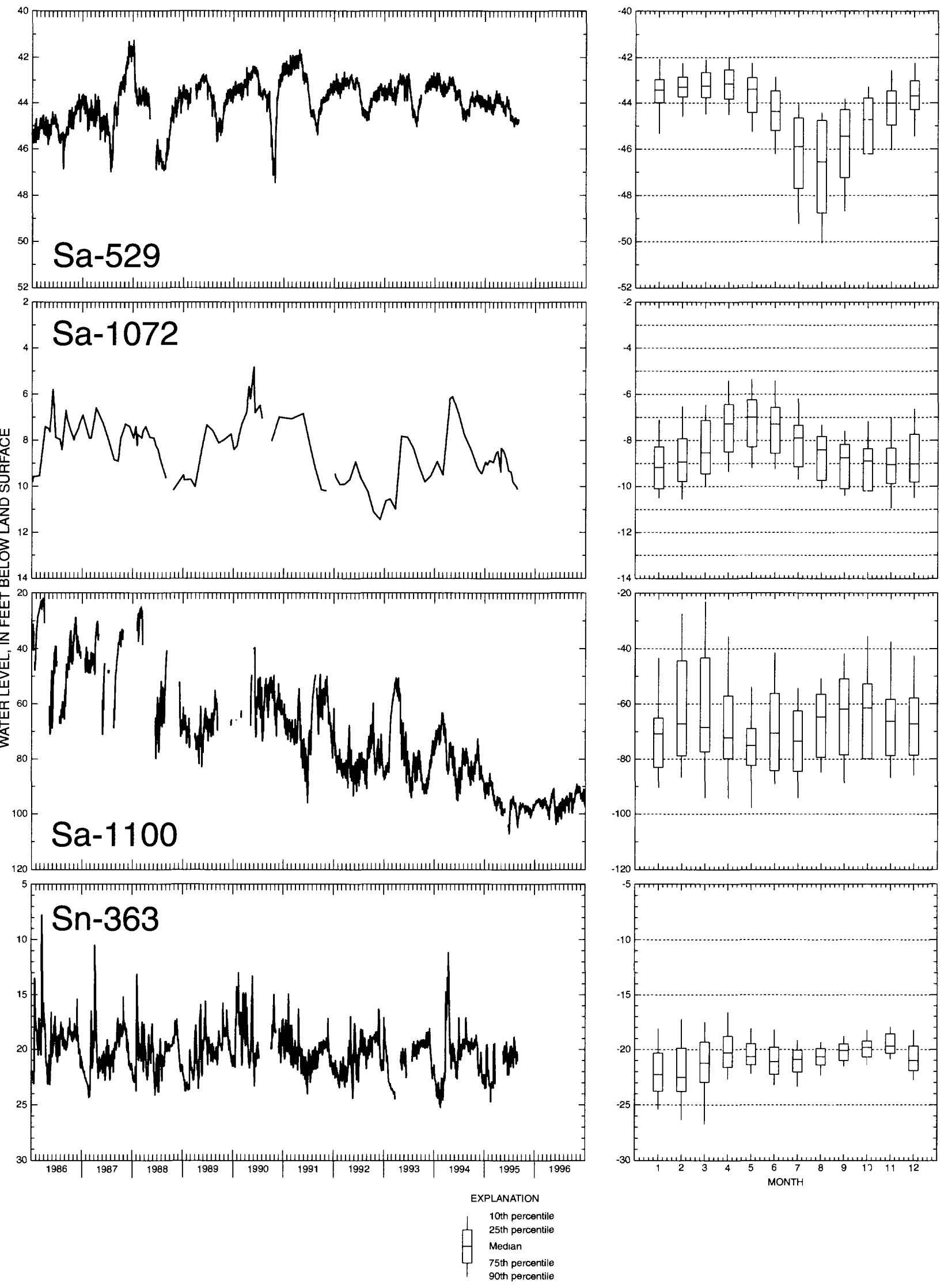

Figure A5. Ten-year hydrographs (1986-96) and boxplots showing median monthly water levels and monthly percentile statistics for observation wells Sa-529 (Saratoga County), Sa-1072 (Saratoga County), Sa-1100 (Saratoga County), and Sn-363 (Schenectady County). 




Figure A6. Ten-year hydrographs (1986-96) and boxplots showing median monthly water levels and monthly percentile statistics for observation wells U-204 (Ulster County), U-405 (Ulster County), W-533 (Washington County), and We-3 (Westchester County). 

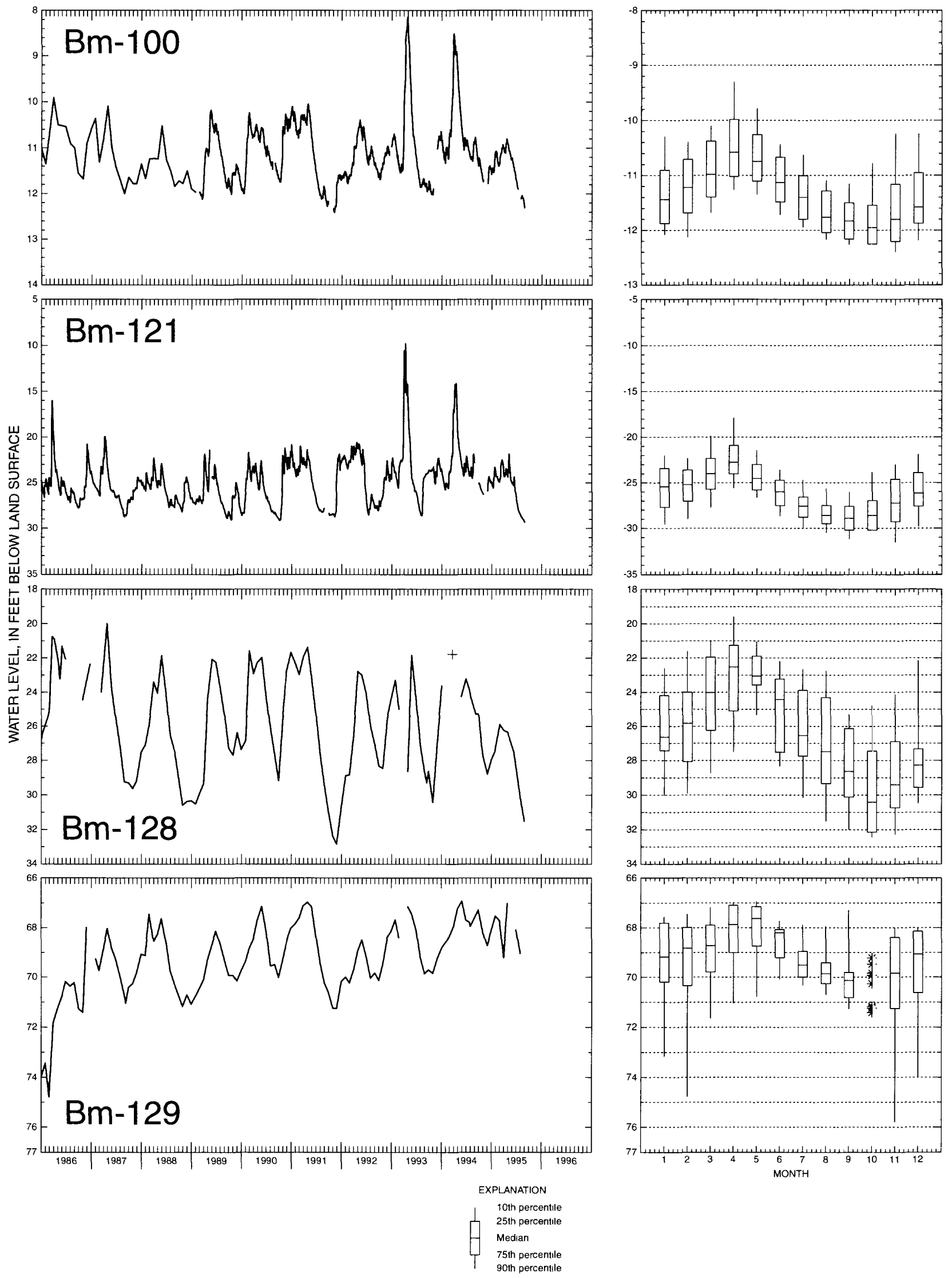

Figure B1. Ten-year hydrographs (1986-96) and boxplots showing median monthly water levels and monthly percentile statistics for observation wells Bm-100 (Broome County), Bm-121 (Broome County), Bm-128 (Broome County), and Bm-128 (Broome County). 


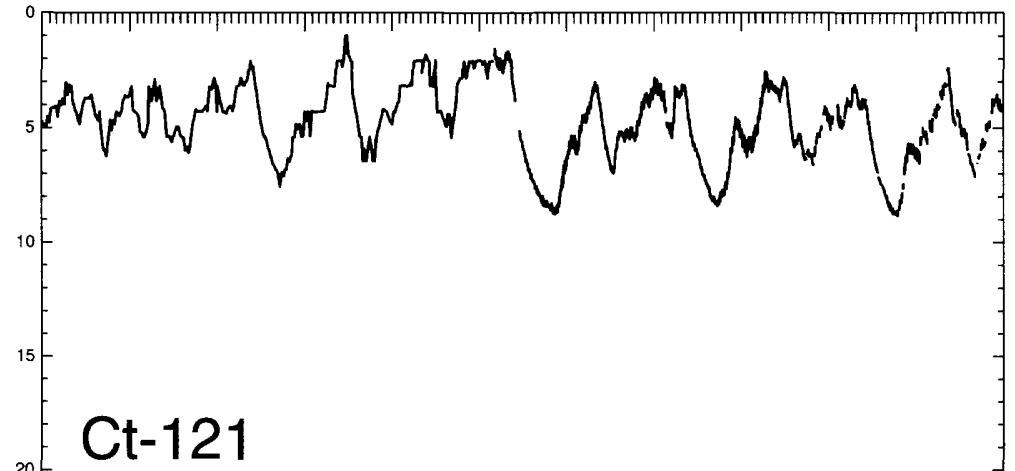

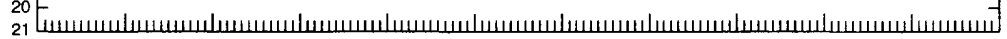

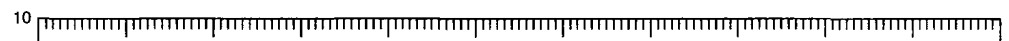

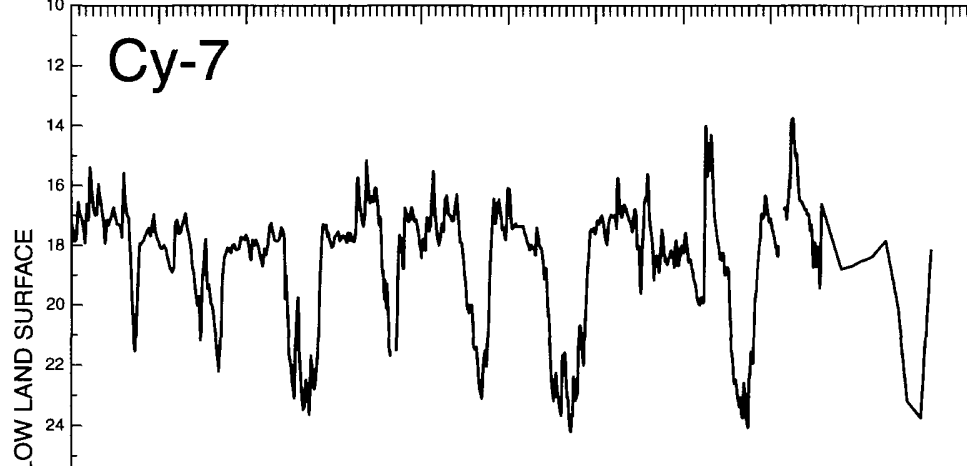

بر 26 رس

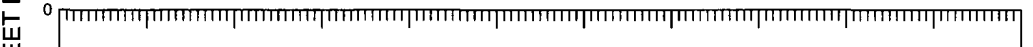

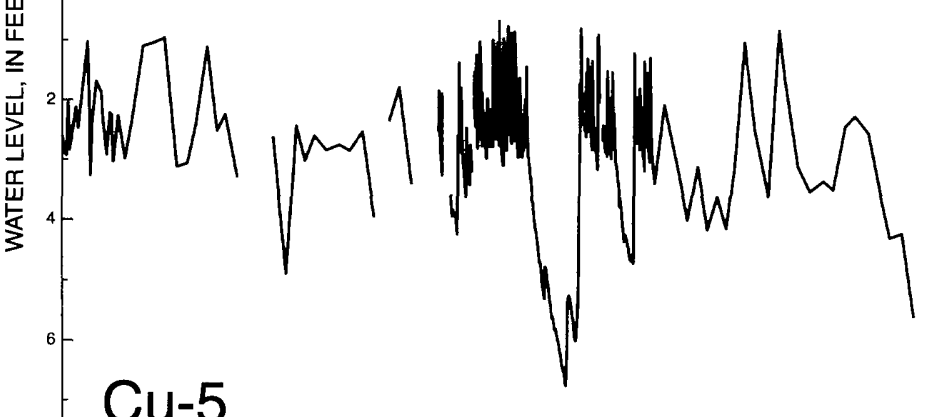

8



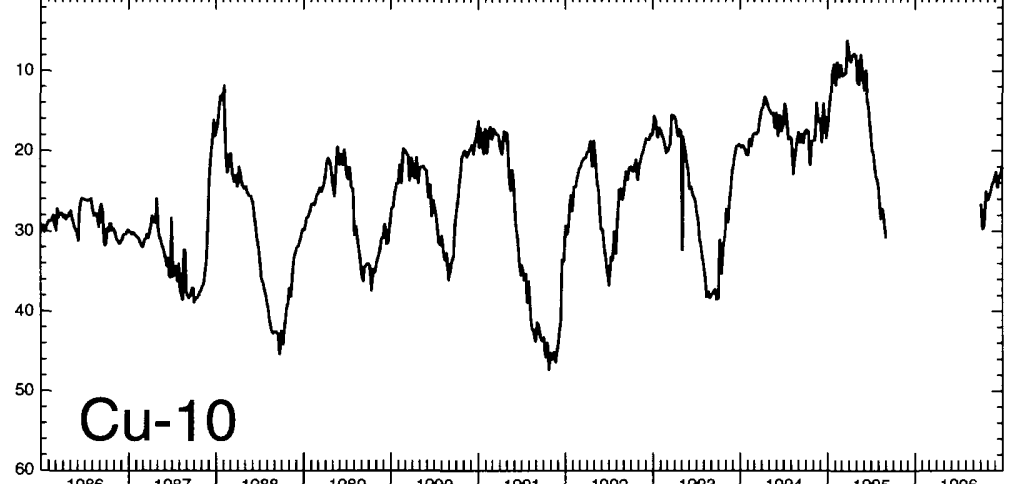

\begin{tabular}{c|c|c|c|c|c|c|c|c|c|}
60 & 1989 & 1990 & 1991 & 1992 & 1993 & 1994 & 1995 & 1996
\end{tabular}

$$
\begin{aligned}
& \text { EXPLANATION } \\
& \begin{array}{|l}
10 \text { th percentle } \\
25 \text { th percentle } \\
\text { Median } \\
75 \text { th percentle }
\end{array}
\end{aligned}
$$
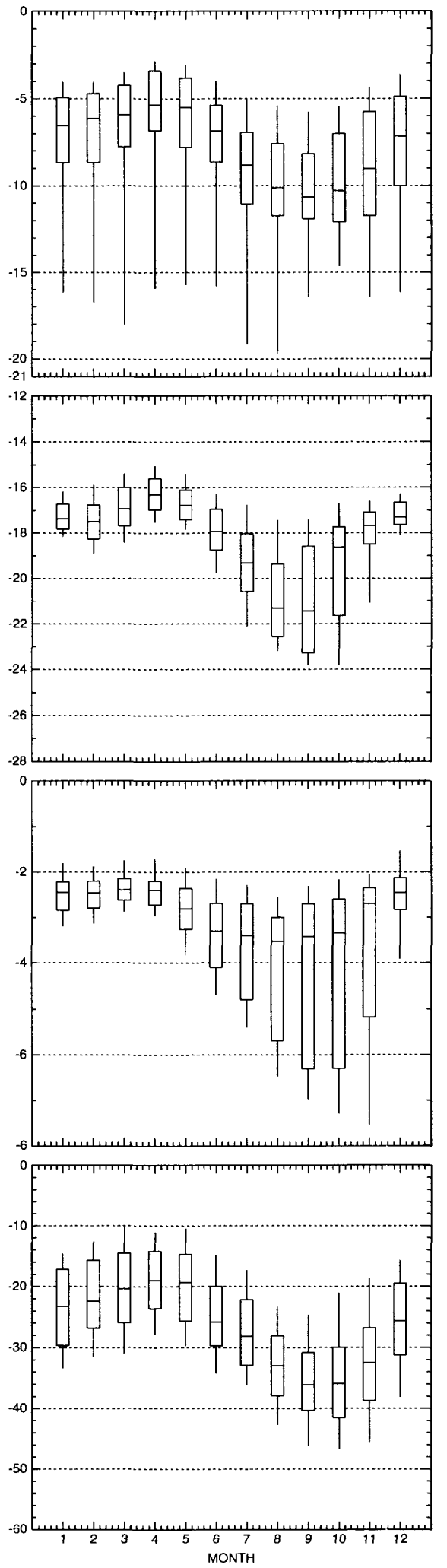

Figure B2. Ten-year hydrographs (1986-96) and boxplots showing median monthly water levels and monthly percentile statistics for observation wells Ct-121 (Cattaraugus County), Cy-7 (Cayuga County), Cu-5 (Chautauqua County), and Cu-10 (Chautauqua County). 

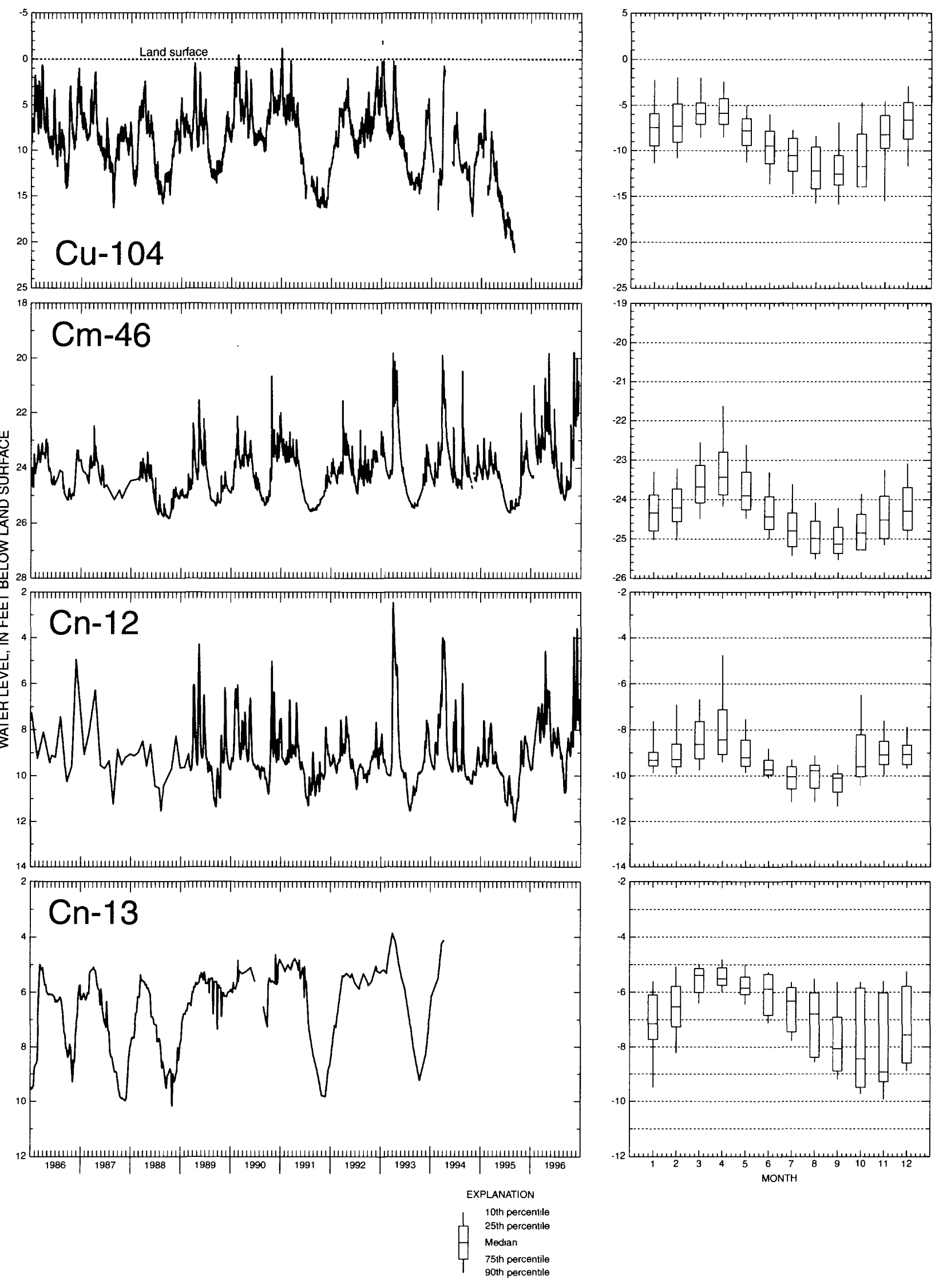

Figure B3. Ten-year hydrographs (1986-96) and boxplots showing median monthly water levels and monthly percentile statistics for observation wells $\mathrm{Cu}-104$ (Chautauqua County), $\mathrm{Cm}-46$ (Chemung County), Cn-12 (Chenango County), and Cn-13 (Chenango County). 
(102)

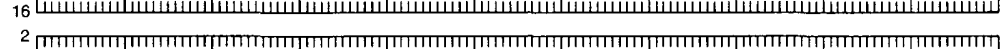

$\mathrm{M}-178$

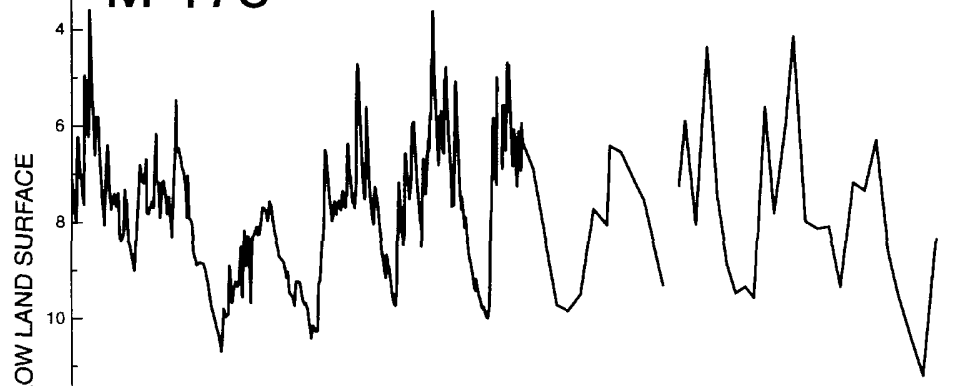

ليسшس

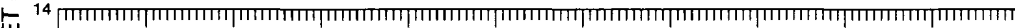

㟧

$\mathrm{Ni}-69$

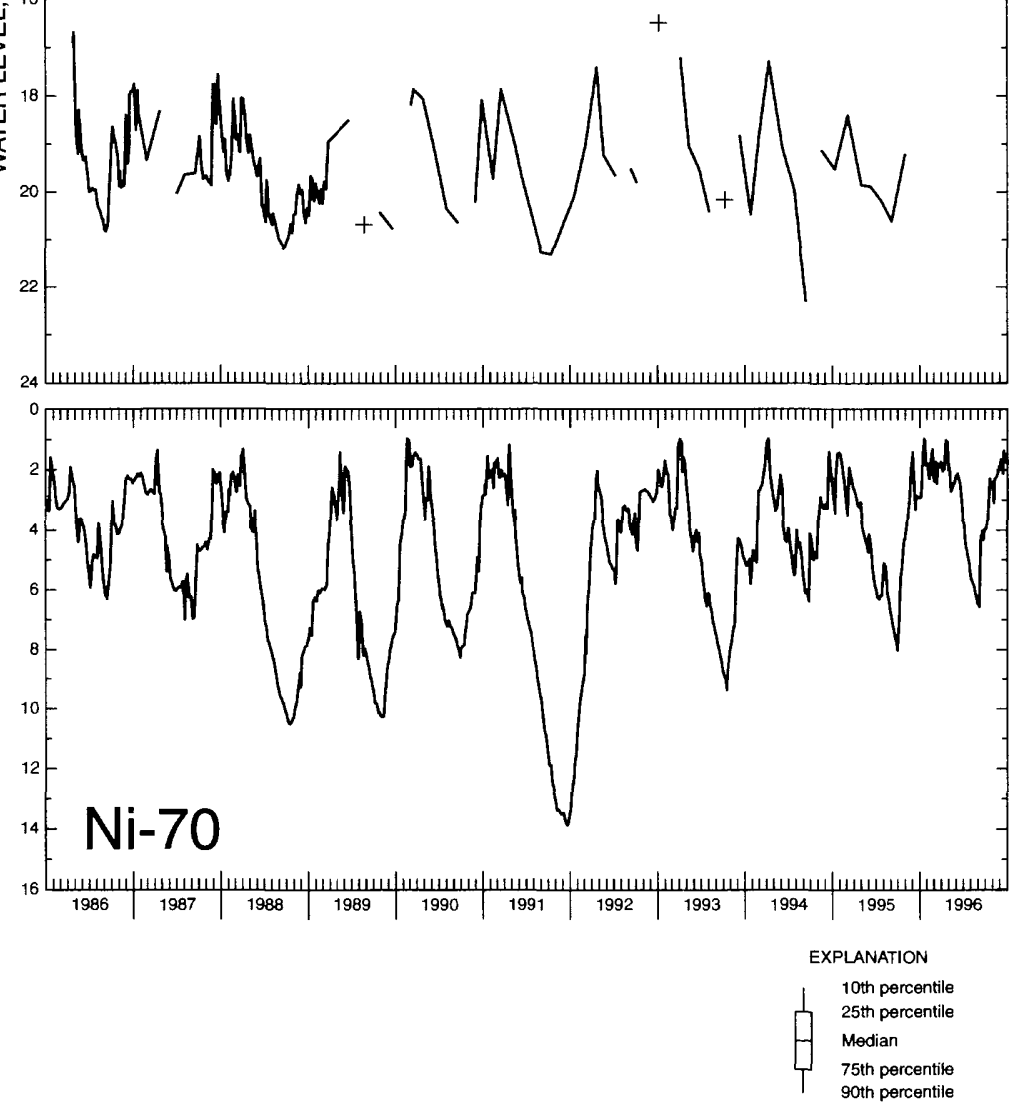

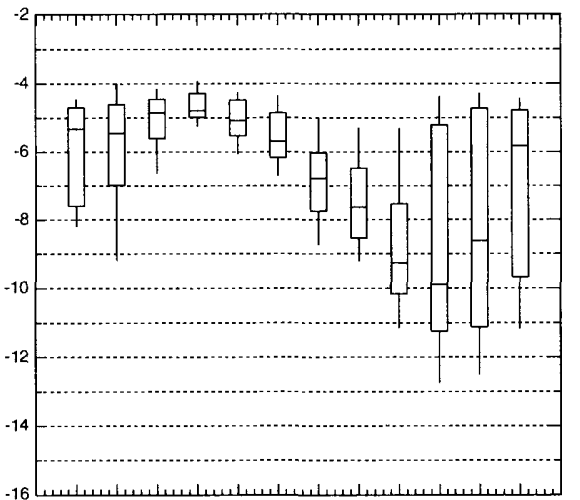
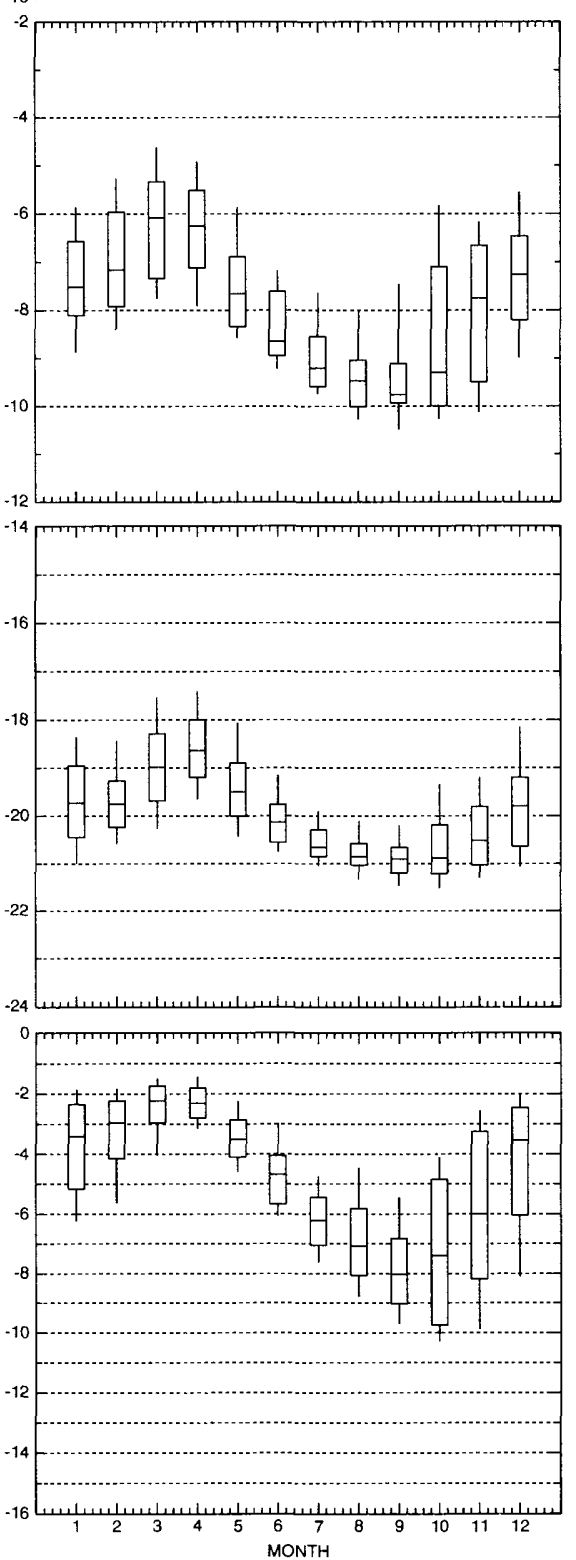

Figure B4. Ten-year hydrographs (1986-96) and boxplots showing median monthly water levels and monthly percentile statistics for observation wells C-102 (Cortland County), M-178 (Madison County), $\mathrm{Ni}-69$ (Niagra County), and Ni-70 (Niagra County). 

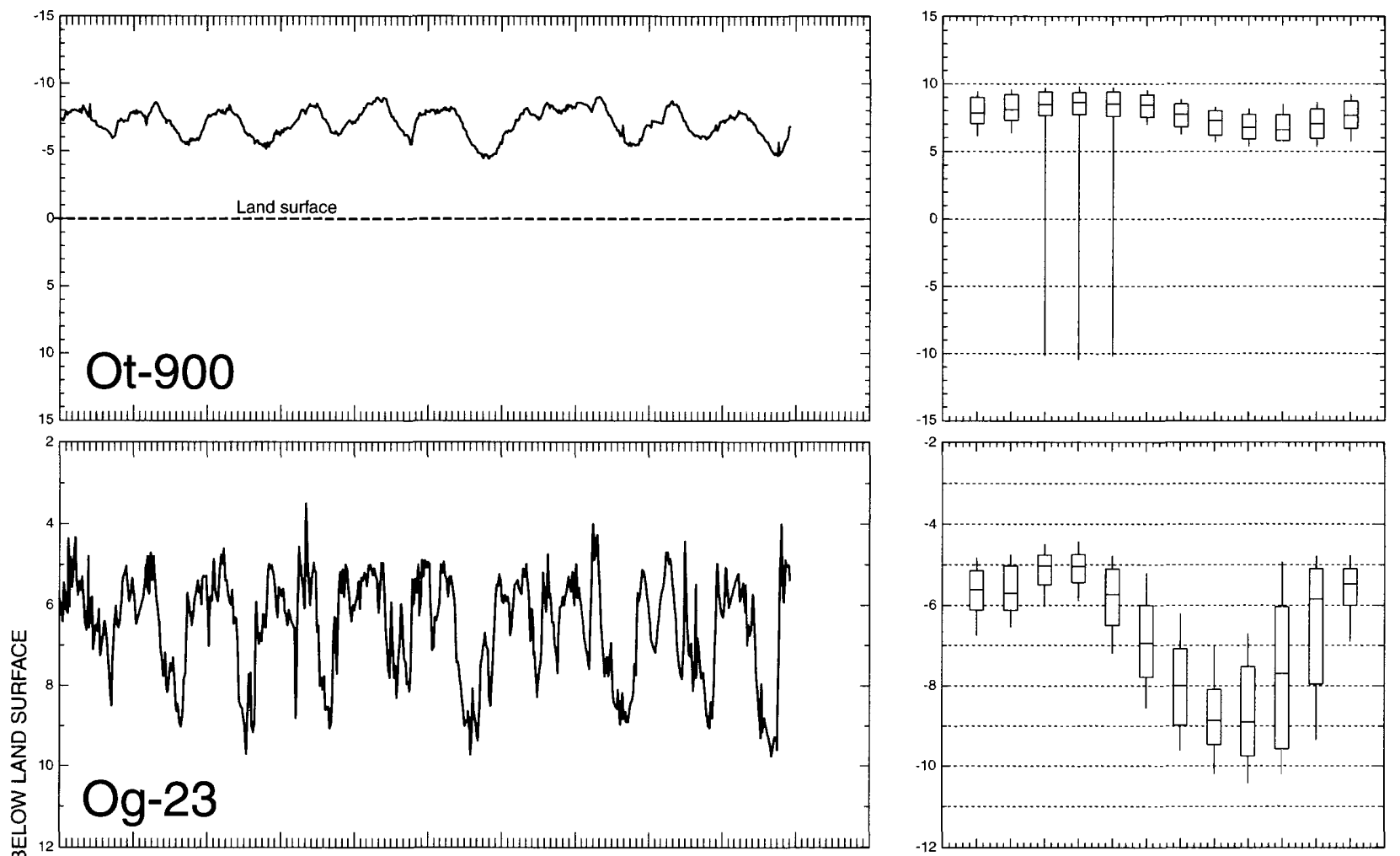

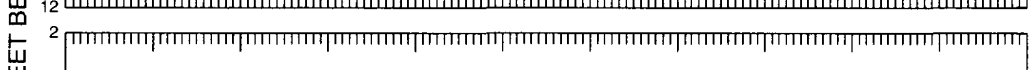

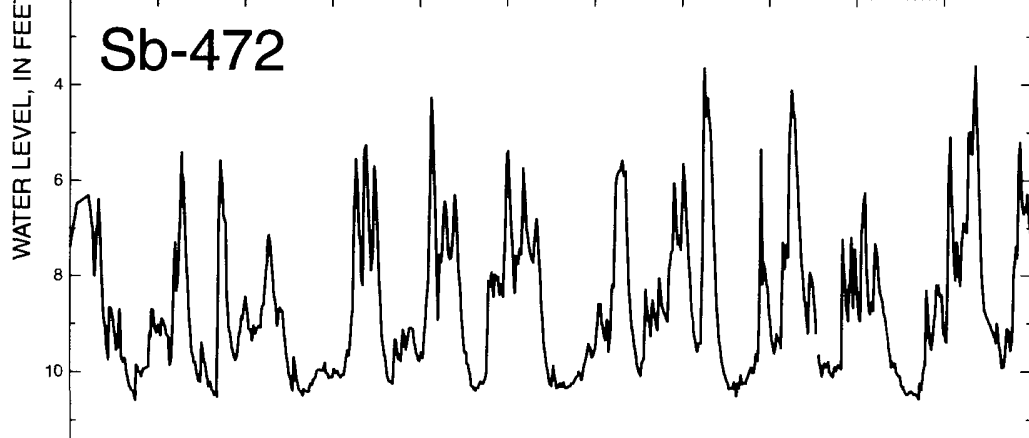

12 لس


Figure B5. Ten-year hydrographs (1986-96) and boxplots showing median monthly water levels and monthly percentile statistics for observation wells Ot-900 (Ontario County), Og-23 (Otsego County), Sb-472 (Steuben County), and Sb-473 (Steuben County). 

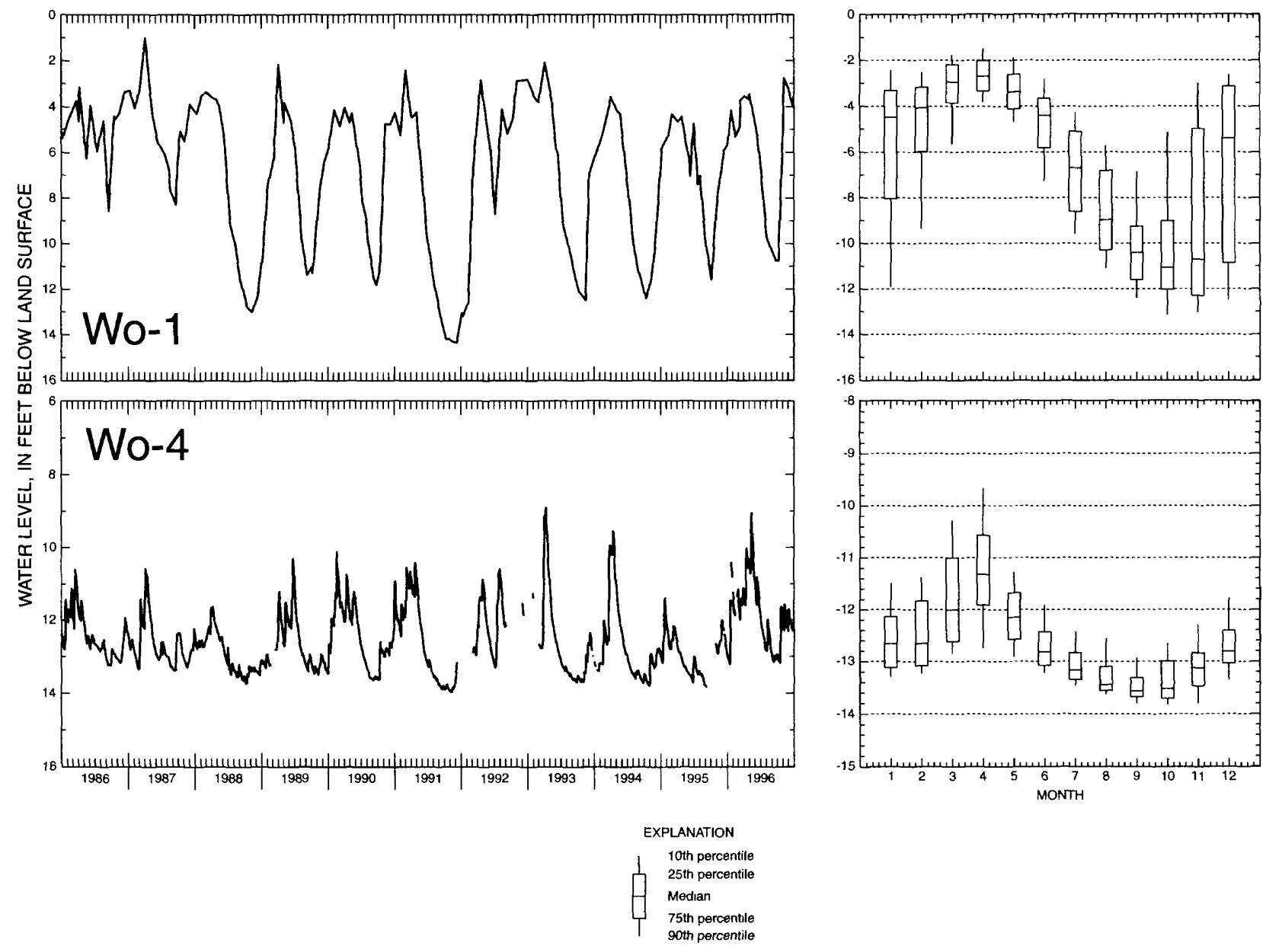

Figure B6. Ten-year hydrographs (1986-96) and boxplots showing median monthly water levels and monthly percentile statistics for observation wells Wo-1 (Wyoming County) and Wo-4 (Wyoming County). 